\title{
Seismic Performance Evaluation of Typical Piers of China's High-Speed Railway Bridge Line Using Pushover Analysis
}

\author{
Wei Guo $\mathbb{D}^{1},{ }^{1,2}$ Yao Hu $\left(\mathbb{D},{ }^{1}\right.$ Hanyun Liu $\mathbb{D},{ }^{1}$ and Dan $B u^{3}$ \\ ${ }^{1}$ School of Civil Engineering, Central South University, Changsha 410075, China \\ ${ }^{2}$ National Engineering Laboratory for High-Speed Railway Construction, Changsha 410075, China \\ ${ }^{3}$ Hunan Architectural Design Institute Limited Company, Changsha 410012, China \\ Correspondence should be addressed to Hanyun Liu; lhy_27@163.com
}

Received 12 April 2019; Revised 3 June 2019; Accepted 12 June 2019; Published 1 July 2019

Academic Editor: Łukasz Jankowski

Copyright (C) 2019 Wei Guo et al. This is an open access article distributed under the Creative Commons Attribution License, which permits unrestricted use, distribution, and reproduction in any medium, provided the original work is properly cited.

\begin{abstract}
Currently, it is a challenge to effectively assess the seismic performance of the high-speed railway bridge line. To figure it out, this paper discussed the applicability of the Pushover analysis in the seismic fragility of the high-speed railway bridge. As the piers are the core components to resist the earthquakes, a typical high-speed railway bridge line consisting of 22 piers was established by the finite element software OpenSees. The influences of the different pier height and sites on the fragility analysis of the pies were investigated. From the component level, the seismic performance of the high-speed railway bridge line was evaluated by the Pushover analysis. The results show that the seismic responses of the piers by the Pushover analysis are agreeable with those by the incremental dynamical analysis when the peak ground acceleration is less than $0.4 \mathrm{~g}$. The high piers have better seismic performance than the lower piers. The high-speed railway bridge line exhibits good seismic performance under the 7-degree design earthquake $(0.15 \mathrm{~g})$ and the 8 -degree low-level earthquake $(0.10 \mathrm{~g})$ but may be severely damaged under the 9 -degree low-level earthquake $(0.40 \mathrm{~g})$.
\end{abstract}

\section{Introduction}

The high-speed railway (HSR) in China is rapidly developing due to its high velocity, safety, and comfort $[1,2]$. The total length of the HSR lines will reach 30,000 kilometres by the end of 2020. With the effect of the mountainous terrain and rivers [3, 4], the HSR bridge is mainly adopted to support the railway line because of its advantages of the high smoothness, standardized design, and easy construction $[5,6]$. For example, the simply supported bridge accounts for $70 \%$ of the Beijing-Shanghai HSR line. However, amounts of bridges are likely to be damaged in the high seismic risk region [7-9]. The Wenchuan earthquake with 8.0 magnitude hit the western area of China on May 12, 2008, causing 6410 bridges to be severely damaged and hard to be repaired [10]. Therefore, the seismic performance evaluation of the HSR bridge is of significance to ensure the normal operation of the HSR bridge line.

Piers, as the core components of the HSR bridge, are designed based on the stiffness. They have distinct characteristics with the large cross section so as to satisfy the requirements of the line smoothness and moving train safety. However, the hysteric curves of the HSR piers in the quasi-static tests [11] show that piers exhibit the low ductility due to the less longitudinal reinforcement ratio. This means that the HSR piers are likely to be damaged under the strong earthquakes. Some studies compared the dynamic responses of the HSR bridge under the vehicle load and the earthquakes [12-14]. It is pointed out that the strong earthquakes have more distinct effect on the responses of the HSR piers [13]. The elastic-plastic deformation may occur at the bottom of the HSR piers under the high-level earthquake [14]. However, these studies only discussed the seismic responses of the HSR bridge under several specific seismic records. The seismic performance of the HSR bridge is not carefully investigated.

The fragility analysis is a common method for the seismic performance evaluation of the structures. It can reflect the probability of the structures exceeding a critical value under a specific seismic intensity [15]. The different methodologies, such as the nonlinear time history analysis and the Pushover 


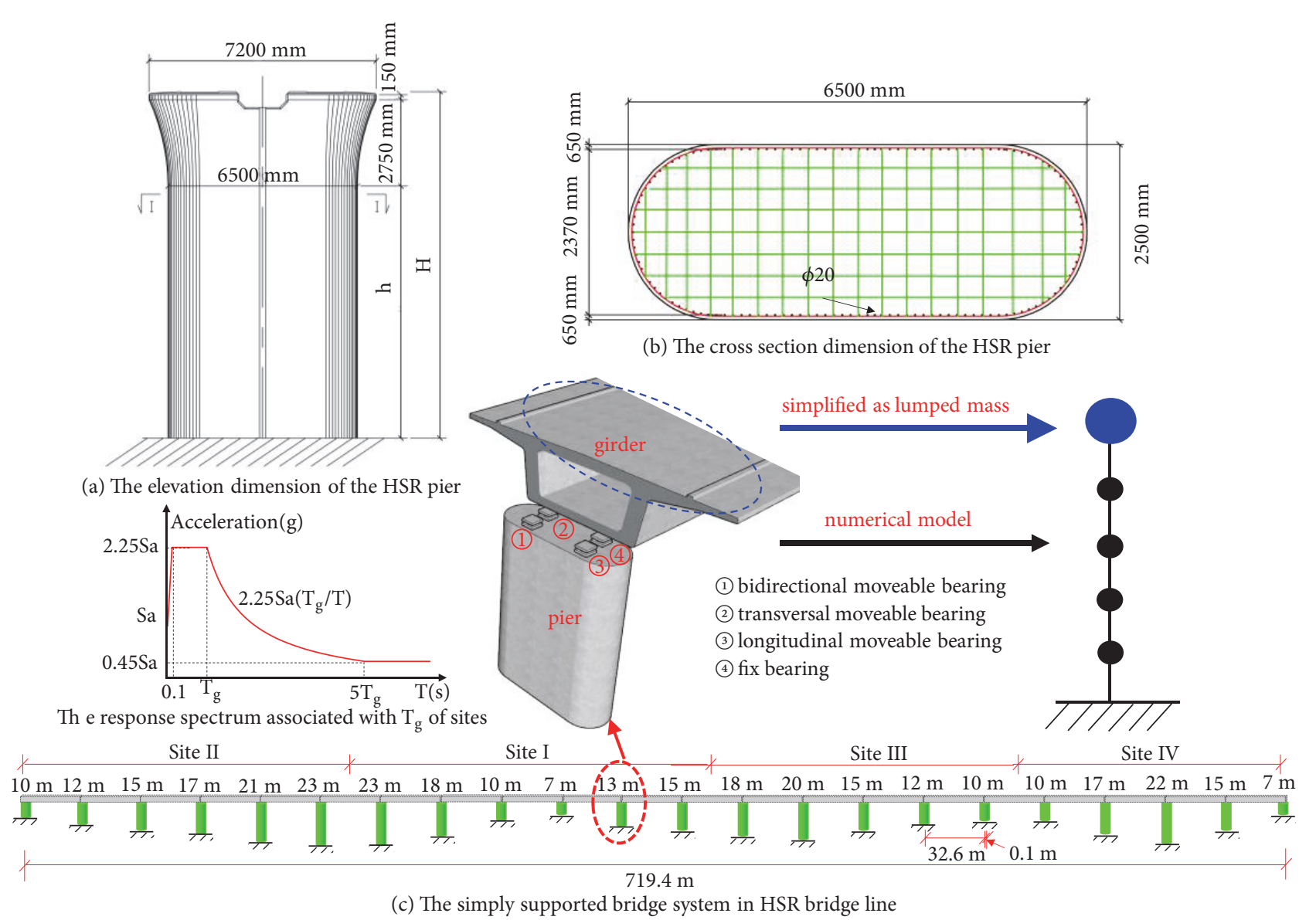

FIgURE 1: Model description of the HSR bridge line.

analysis, are widely adopted for the seismic fragility analysis of the highway bridge [16-21]. The nonlinear time history analysis is more reliable and accurate, while the Pushover analysis has the distinct advantages of the conceptual simplicity and the computational effectiveness [22, 23]. Moreover, the seismic fragility of the highway bridges by the Pushover analysis is aggregable with those obtained from the nonlinear time history analysis [24]. The Pushover analysis provides a more practical-oriented alternative for the seismic performance evaluation of the highway bridges [25]. However, the HSR bridge is designed by the stiffness, which is different from the design of the highway bridge. The applicability of the Pushover analysis in the seismic analysis of the HSR bridge is not clear. To figure it out, this paper will extend the application of the Pushover analysis into the seismic evaluation of the HSR piers.

In the current seismic code of China [26], the simply supported bridge is recommendable to be established as the simply pier or the bridge model for the seismic analysis. In this paper, the 22 HSR pier models with the different height and four types of sites were established by the finite element software OpenSees. The application of the Pushover analysis into the seismic evaluation of the HSR piers will be carefully investigated. The seismic performance of the HSR piers and the whole bridge line will be evaluated using the Pushover analysis.

\section{Model Description of the HSR Bridge Piers}

For the simply supported bridge system, the total length of the girder for each span is 32.6 meters, and the clear spacing between two adjacent spans is 0.1 meters. Four bearings are located on the pier to support the girder. They are the fixed bearing, longitudinal moveable bearing, transverse moveable bearing, and bidirectional moveable bearing. The girder usually keeps elastic under the earthquakes. According to the seismic code in China [26], the simply supported bridge is recommended to be established as the single pier model for the seismic analysis. For the seismic analysis in the longitudinal direction of the simply supported bridge, the girder is simplified as the lumped mass at the top of the numerical model of piers, as shown in Figure 1. Based on this, the simply supported bridge is established as the single pier model by the Open System for Earthquake Engineering Simulation (OpenSees).

The HSR bridge piers with the round-shaped cross section are one of the most common piers adopted in the simply supported bridge. Different from the highway bridge [27], the HSR piers are designed by the stiffness with the characteristics of the large cross section. The dimensions of the HSR pier are shown in Figures 1(a) and 1(b). The design strength of the concrete is $23.4 \mathrm{MPa}$. The longitudinal reinforcement ratio and the axial compression ratio are $0.75 \%$ 
TABLE 1: The site types in Chinese code.

\begin{tabular}{lccc}
\hline Site & Site type & Shear-wave velocity $(\mathrm{m} / \mathrm{s})$ & Characteristic period $\left(\mathrm{T}_{\mathrm{g}}\right)$ \\
\hline Site I & rock & $\mathrm{V}_{\mathrm{s}}>500$ & $0.35 \mathrm{~s}$ \\
Site II & medium-hard soil & $250<\mathrm{V}_{\mathrm{s}} \leq 500$ & $0.45 \mathrm{~s}$ \\
Site III & medium-soft soil & $150<\mathrm{V}_{\mathrm{s}} \leq 250$ & $0.65 \mathrm{~s}$ \\
Site IV & soft soil & $\mathrm{V}_{\mathrm{s}} \leq 150$ & $0.90 \mathrm{~s}$ \\
\hline
\end{tabular}

TABLE 2: The damage state of the piers defined by the displacement ductility coefficient.

\begin{tabular}{|c|c|c|}
\hline Damage states & Damage description of the piers & Limits \\
\hline No damage & No steel bars yield, and the concrete cracks begin to occur. & $0<\mu \leq \mu_{c y 1}$ \\
\hline Slight damage & The first steel bar begins to yield, and the concrete cracks are extended. & $\mu_{c y 1}<\mu \leq \mu_{c y}$ \\
\hline Moderate damage & The plastic hinges begin to form, and the concrete begins to peel off. & $\mu_{c y}<\mu \leq \mu_{c 4}$ \\
\hline Severe damage & $\begin{array}{l}\text { The plastic hinges are completely formed, the cracks are widely extended, and the } \\
\text { concrete peels off at the plastic hinges. }\end{array}$ & $\mu_{c 4}<\mu \leq \mu_{c \max }$ \\
\hline Complete damage & $\begin{array}{l}\text { The strength of the pier begins to be degraded, the reinforcements and stirrups } \\
\text { yield, and the core concrete is crushed. }\end{array}$ & $\mu_{c \max }<\mu$ \\
\hline
\end{tabular}

and $10 \%$, respectively. Concrete 02 and Steel02 material are used to simulate the concrete and longitudinal reinforcement, respectively. The total weight of the girder for each span is 1360 tonnes, which is regarded as the lumped mass at the top node of piers. In this paper, the 22 HSR piers of the simply supported bridge system are established to compose the HSR bridge line, as shown in Figure 1(c). The influence of the different heights is considered in the pier's finite element model. The effect of each site is included by adopting the different response spectrum associated with the characteristic period of the soil, as shown in Table 1 and Figure 1.

\section{Definition of the Pier's Damage Limit}

The hysteric curves of the HSR piers with $8 \mathrm{~m}, 16 \mathrm{~m}$, and $24 \mathrm{~m}$ were tested by the low cyclic load $[11,28]$. The bending damage was the failure mode of these HSR piers. The experiment showed that the first crack occurred at the bottom of the pier, and then more cracks extended as the reinforcement began to yield. Based on this, the different damage limits of the HSR piers are descripted by the displacement ductility coefficient $\mu$, which is expressed as [11]

$$
\mu=\frac{d}{\Delta_{c y 1}}
$$

where $d$ (unit: $m$ ) is the maximum displacement at the top of the HSR pier relative to the ground; $\Delta_{c y 1}$ (unit: $m$ ) represents the relative displacement of piers corresponding to the first yield of the longitudinal reinforcement. According to literatures $[29,30]$, the different damage state of the pier is shown in Table 2.

In Table 2, $\mu_{c y 1}$ represents the displacement ductility coefficient when the steel bars begin to yield, which is the upper limit of the slight damage state; $\mu_{c y}$ is the yield displacement ductility coefficient of the piers, representing
TABLE 3: The damage state limits of the HSR piers with different heights.

\begin{tabular}{lcccc}
\hline Height of the pier & $\mu_{c y 1}$ & $\mu_{c y}$ & $\mu_{c 4}$ & $\mu_{c \max }$ \\
\hline $7 \mathrm{~m}$ & 1.00 & 1.21 & 3.17 & 6.17 \\
$10 \mathrm{~m}$ & 1.00 & 1.21 & 3.06 & 6.06 \\
$12 \mathrm{~m}$ & 1.00 & 1.21 & 3.02 & 6.02 \\
$13 \mathrm{~m}$ & 1.00 & 1.21 & 3.00 & 6.00 \\
$15 \mathrm{~m}$ & 1.00 & 1.21 & 2.98 & 5.98 \\
$17 \mathrm{~m}$ & 1.00 & 1.21 & 2.96 & 5.96 \\
$18 \mathrm{~m}$ & 1.00 & 1.21 & 2.95 & 5.95 \\
$20 \mathrm{~m}$ & 1.00 & 1.21 & 2.87 & 5.87 \\
$21 \mathrm{~m}$ & 1.00 & 1.21 & 2.80 & 5.80 \\
$22 \mathrm{~m}$ & 1.00 & 1.21 & 2.73 & 5.73 \\
$23 \mathrm{~m}$ & 1.00 & 1.21 & 2.66 & 5.66 \\
\hline
\end{tabular}

the upper limit of the moderate damage state; $\mu_{c 4}$ corresponds to the displacement ductility coefficient when the concrete is cracked at the strain of 0.002 and is the upper limit of the severe damage state; $\mu_{c \max }$ is the maximum displacement ductility ratio and is the complete damage upper limit.

The damage state limits of the piers with the different heights can be calculated according to the literature $[27,29$, 30], as shown in Table 3 . The ductility coefficient of the tested HSR piers ranges from 3 to 6 [11]. In Table 3, the displacement ductility coefficient of the HSR piers with the different heights is less than 3.5 in the severe damage state, which indicates that the HSR piers have the low ductility.

\section{Comparison of the Performance Evaluation Methods}

4.1. The Procedure of the Pushover and IDA Methods. In this section, the computational efficiency and accuracy of 
the Pushover analysis and the incremental dynamic analysis (IDA) are compared in the seismic analysis of the HSR piers. In the Pushover methodology, it is important to select the lateral load pattern, such as the suggested inverted triangle distribution (modal pattern), uniform distribution, and the adaptive distribution [31, 32]. The selected load pattern is used for the nonlinear static analysis step by step until the capacity curve of the structures is obtained. In this paper, it is assumed that the seismic response of the HSR pier is controlled by the first mode vibration. The load pattern with the first mode vibration remains constant throughout the Pushover analysis [26], specified as (2). To identify the strength and displacement quantities, the simplified bilinear base shear-roof displacement curves of the HSR piers need to define the properties of the HSR piers. The transformation from the simplified bilinear curve into the capacity curve is calculated by (3).

$$
\begin{aligned}
F_{i} & =\alpha \beta_{1} \gamma_{1} x_{i} m_{i} \\
S_{a} & =\frac{V_{b}}{M_{1}}, \\
S_{d} & =\frac{D_{b}}{\gamma_{1} \varphi_{n 1}}, \\
M_{1} & =\frac{\left(\sum_{i=1}^{n} m_{i} \varphi_{i 1}\right)^{2}}{\sum_{i=1}^{n} m_{i} \varphi_{i 1}^{2}} \\
\gamma_{1} & =\frac{\sum_{i=1}^{n} m_{i} \varphi_{i 1}}{\sum_{i=1}^{n} m_{i} \varphi_{i 1}^{2}}
\end{aligned}
$$

where $F_{i}$ (unit: $k N$ ) is the horizontal seismic load of the ith node at the first model; $\alpha$ (unit: $g$ ) is the horizontal acceleration; $\beta_{1}$ is the dynamic amplification factor of the HSR pier at the first mode; $\gamma_{1}$ is the mode participation coefficient at the first model; $\mathrm{x}_{\mathrm{i}}$ is the modal coordinate of the ith node at the first model; $m_{i}$ (unit: $\mathrm{kg}$ ) is the mass of the ith node; $S_{a}$ (unit: $g$ ) is the pseudo acceleration; $S_{d}$ (unit: $m$ ) is the pseudo displacement; $\mathrm{V}_{\mathrm{b}}$ (unit: $k N$ ) is the maximum base shear of the pier; $D_{b}$ (unit: $m$ ) is the roof displacement of the pier; $M_{1}$ (unit: $\mathrm{kg}$ ) is the effective mass of the HSR pier at the first model; $\varphi_{i 1}$ is the displacement of the ith node at the first mode; and $\varphi_{n 1}$ is the roof displacement of the piers at the first modal.

The target displacement of the HSR piers is determined by the intersection of the inelastic demand spectra and the capacity curve. The inelastic demand spectra for each site are given by the reduction of the elastic response spectrum related to the characteristic period of the soil. It reflects changes in the stiffness and damping associated with the maximum displacement response of the structure. The reduction of the structural stiffness is described by the secant stiffness [30] related to the equivalent period, defined as (4a). The equivalent viscous damping ratio $\zeta_{\text {eff }}$ is used to describe the changes of the structural damping. It represents the energy dissipation of structures in one cycle of the vibration [33]. Considering the pitching phenomenon of structures, the modified equivalent damping ratio $[34,35]$ is expressed as (4b).

$$
\begin{aligned}
& T_{e q}=T_{n} \sqrt{\frac{\mu}{1+\alpha_{s} \mu-\alpha_{s}}}, \\
& \zeta_{e f f}=\zeta_{0}+\frac{2}{\pi} \eta \frac{\left(1-\alpha_{s}\right)(1-1 / \mu)}{1-\alpha_{s}+\mu \alpha_{s}}
\end{aligned}
$$

where $T_{n}$ (unit: $s$ ) is the fundamental period of structures; $\alpha_{s}$ is the ratio of the postyield stiffness to the preyield stiffness; and $\mu$ is the displacement ductility coefficient, which represents the ratio of the maximum displacement to the postyield displacement of structures; $\zeta_{0}$ is the viscous damping ratio of the structures in the elastic state; and 0.05 is adopted for the reinforced concrete structure; $\eta$ is the damping modification factor, which is the effective ratio of the energy dissipation of the real hysteresis of the structure to that of the simplified bilinear model.

The incremental dynamic analysis (IDA) [36] is commonly used for the seismic analysis of structures by employing the nonlinear time history analysis. This methodology can reflect the probabilistic distribution of the structural response under a suite of ground motion records, as shown in Figure 3.

In the IDA method, each ground motion is scaled to the different level of intensity in the nonlinear dynamic analysis. In this paper, the influence of four types of sites is included in the seismic analysis of the HSR pier by the IDA. Based on the seismic code in China [26], the ten seismic records are selected to match the design response spectrum associated with the characteristic period of each site. The deviations of the mean spectra of the selected records and the design spectra are less than $20 \%$ in the critical periods in Figure 4, which satisfies the requirements of the seismic record selection in the seismic code [26]. All seismic records are obtained from the database of the Pacific Earthquake Engineering Research Center (PEER) [37], as shown in Table 4.

4.2. Efficiency Comparison. According to the flowcharts shown in Figures 2 and 3, the seismic responses of the HSR piers can be calculated by the Pushover analysis and IDA. The used computer information is shown in Table 5. The cost time of two methods is shown in Table 6 . The cost time ratio by the Pushover analysis and IDA is $1: 88$, which indicates that the Pushover analysis is more computationally effective than the IDA.

4.3. Accuracy Comparison. The IDA can accurately reflect the seismic responses of the HSR piers under the earthquakes by employing the nonlinear history analysis. However, the Pushover analysis can only approximately describe the seismic responses of the HSR piers. Therefore, the calculation accuracy is worth attention. The seismic responses of the HSR pier model by Pushover analysis are compared with those by IDA in the following part.

4.3.1. The Fragility Analysis. The fragility analysis is widely used for the seismic vulnerability assessment of structures 
TABLE 4: The selected seismic records from PEER.

\begin{tabular}{|c|c|c|c|c|}
\hline Records & Name/station on site I & Name/station on site II & Name/station on site III & Name/station on site IV \\
\hline 1 & Chi-Chi Taiwan/CHY050 & Morgan Hill/Capitola & Chi-Chi Taiwan/CHY015 & Tottori Japan/SMN002 \\
\hline 2 & Chi-Chi Taiwan/CHY050 & $\begin{array}{l}\text { San Fernando/Whittier } \\
\text { Narrows Dam }\end{array}$ & Chi-Chi Taiwan/CHY047 & Tottori Japan/SMN002 \\
\hline 3 & Iwate/Tsuchizaki & $\begin{array}{l}\text { San Fernando/Whittier } \\
\text { Narrows Dam }\end{array}$ & $\begin{array}{l}\text { Imperial Valley-06/El } \\
\text { Centro Array \# }\end{array}$ & Iwate/IWT020 \\
\hline 4 & $\begin{array}{c}\text { Whittier } \\
\text { Narrows-01/Luconia }\end{array}$ & $\begin{array}{l}\text { San Fernando/Whittier } \\
\text { Narrows Dam }\end{array}$ & $\begin{array}{l}\text { Imperial Valley-06/El } \\
\text { Centro Array \#13 }\end{array}$ & $\begin{array}{c}\text { Darfield New } \\
\text { Zealand/Christchurch } \\
\text { Resthaven }\end{array}$ \\
\hline 5 & $\begin{array}{c}\text { Loma Prieta/Calaveras } \\
\text { Reservoir }\end{array}$ & Tabas Iran/Ferdows & $\begin{array}{l}\text { Northern Calif-03/Ferndale } \\
\text { City Hall }\end{array}$ & $\begin{array}{c}\text { Darfield New } \\
\text { Zealand/Christchurch } \\
\text { Resthaven }\end{array}$ \\
\hline 6 & Chi-Chi Taiwan/ILA067 & $\begin{array}{c}\text { Imperial } \\
\text { Valley-06/Coachella Canal } \\
\# 4\end{array}$ & $\begin{array}{c}\text { Chi-Chi } \\
\text { Taiwan-04/CHY047 }\end{array}$ & $\begin{array}{c}\text { Loma Prieta/Foster City - } \\
\text { APEEL }\end{array}$ \\
\hline 7 & $\begin{array}{c}\text { Taiwan } \\
\text { SMART1(40)/SMART1 O07 }\end{array}$ & $\begin{array}{c}\text { Mammoth } \\
\text { Lakes-06/Benton }\end{array}$ & $\begin{array}{c}\text { Chi-Chi } \\
\text { Taiwan-06/CHY037 }\end{array}$ & $\begin{array}{c}\text { Loma Prieta/Foster City - } \\
\text { APEEL }\end{array}$ \\
\hline 8 & N. Palm Springs/Indio & $\begin{array}{c}\text { Kern County/Taft Lincoln } \\
\text { School }\end{array}$ & $\begin{array}{c}\text { Chi-Chi } \\
\text { Taiwan-06/TCU141 }\end{array}$ & $\begin{array}{c}\text { Loma Prieta/Foster City - } \\
\text { Menhaden Court }\end{array}$ \\
\hline 9 & Big Bear-01/Snow Creek & $\begin{array}{c}\text { Victoria Mexico/SAHOP } \\
\text { Casa Flores }\end{array}$ & Iwate/Furukawa Osaki City & $\begin{array}{c}\text { Loma Prieta/Foster City - } \\
\text { Menhaden Court }\end{array}$ \\
\hline 10 & $\begin{array}{l}\text { Northridge-01/Antelope } \\
\text { Buttes }\end{array}$ & Tabas Iran/Ferdows & $\begin{array}{l}\text { El Mayor-Cucapah/Bonds } \\
\text { Corner }\end{array}$ & $\begin{array}{c}\text { Loma Prieta/Foster City - } \\
\text { Menhaden Court }\end{array}$ \\
\hline
\end{tabular}

TABLE 5: The information of computer for the seismic analysis of the HSR piers.

\begin{tabular}{lc}
\hline Systems & Computer configuration \\
\hline $\begin{array}{l}\text { Processor } \\
\text { Random access memory (RAM) }\end{array}$ & Intel(R) Xeon(R) CPU E5-2637 v2 @ 3.50GHz 3.50 GHz (2 processors) \\
The operating system & $64.0 \mathrm{~GB}$ \\
The computer name & 64-bit operating system, x64 based processor \\
\hline
\end{tabular}

TABLE 6: Comparisons of the calculation efficiency of the Pushover analysis and the IDA.

\begin{tabular}{lcccccc}
\hline Method & $N_{e}$ & $N_{g}$ & $N_{\text {case }}$ & $T_{\text {com }}$ & $T_{\text {total }}=N_{e} \times N_{g} \times N_{\text {case }} \times T_{\text {com }}$ & Efficiency \\
\hline Pushover & -- & $1 / 0.05$ & 22 & $161 \mathrm{sec}$ & $70840 \mathrm{sec}$ & $1: 88$ \\
IDA & 10 & $1 / 0.05$ & 22 & $1421 \mathrm{sec}$ & $6252400 \mathrm{sec}$ & \\
\hline
\end{tabular}

Here, $N_{e}$ is the number of the selected seismic records on each site; $N_{g}$ is the number of the seismic records scaled from $0.05 \mathrm{~g}$ to $1.0 \mathrm{~g}$ with an increment of $0.05 \mathrm{~g} ; N_{\text {case }}$ is the total number of the HSR pier models; and $T_{\text {com }}$ is the required calculation time for seismic analysis of the HSR pier model (sec).

[18]. The fragility curves represent the damage probability of structures at a given earthquake intensity, which is described by the lognormal cumulative distribution function [38, 39]. The fragility probability of the structures is given by

$$
P(D S>P L \mid P G A)=\phi\left(\frac{\ln (P G A)-\ln \left(P G A_{P L}\right)}{\beta_{c}}\right)
$$

in which $P$ is the damage probability of the HSR piers at a given earthquake intensity. $P G A_{P L}$ denotes the peak ground acceleration (PGA) corresponding to a $50 \%$ damage probability, and $\beta_{c}$ describes the uncertainties related to the structural properties and seismic characteristics.
The fragility curves of the HSR piers with the different heights in the different damage states can be obtained by (5). The fragility curves of the HSR piers on site II (medium-hard soil) are shown in Figure 5.

The fragility curves of the HSR piers by the Pushover analysis are different from those by the IDA. For most of the HSR piers, the damage probability error by the Pushover analysis is increasing as PGA increases. However, the calculation error induced by the Pushover analysis is less than $20 \%$. When PGA is not greater than $0.4 \mathrm{~g}$, the fragility curves obtained from the Pushover analysis are agreeable with those by the IDA. The damage probability calculated by the Pushover analysis is generally larger than that by the IDA. This indicates that 

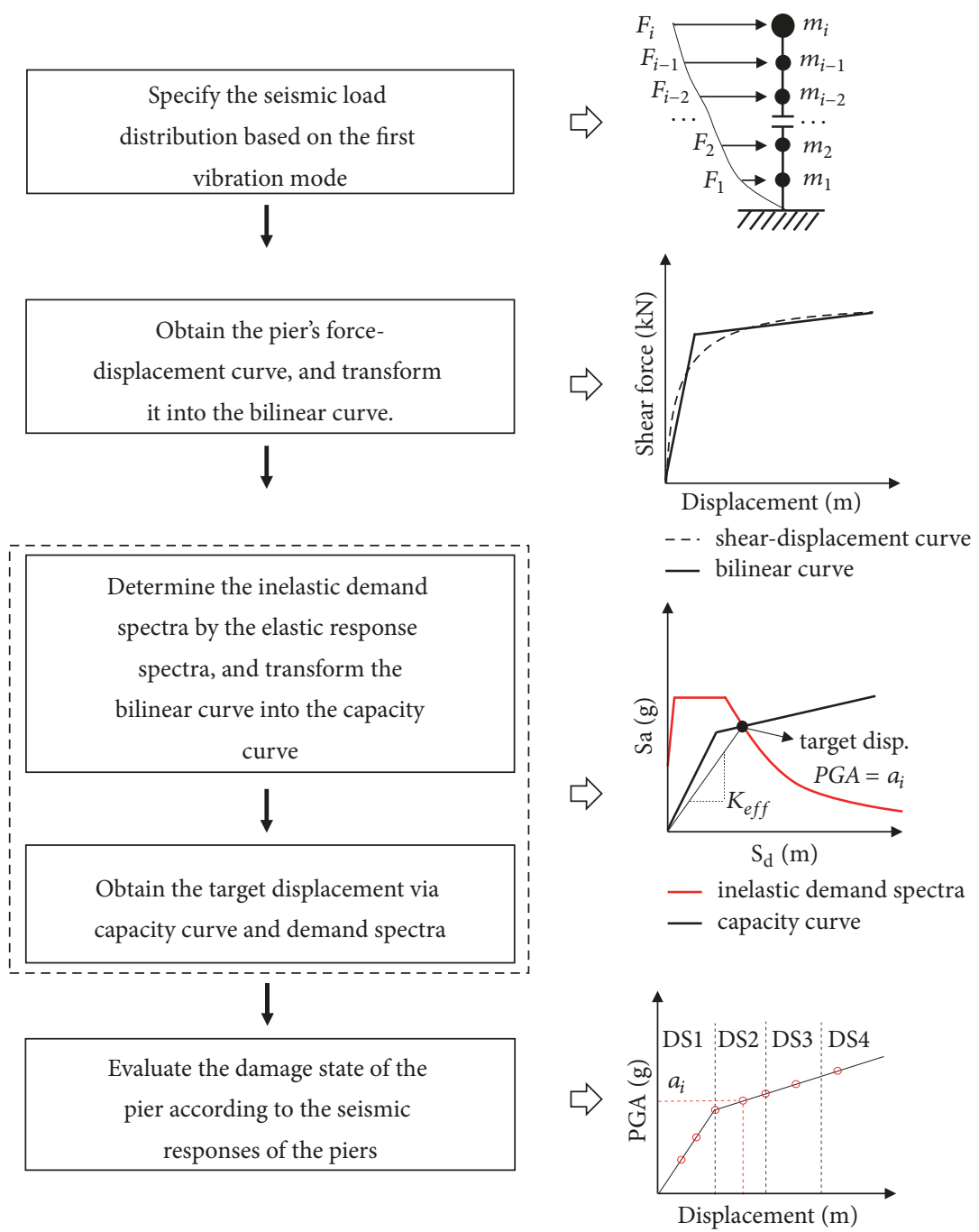

Figure 2: The flowchart of the Pushover analysis.

the seismic performance of the HSR piers is underestimated by the Pushover analysis. In other words, when the Pushover analysis is applied to analyse the seismic fragility of the HSR piers with PGA less than $0.4 \mathrm{~g}$, the safety of the HSR piers is adequate from the perspective of the practical engineering.

4.3.2. The Effective Height Ratio Analysis. The time history analysis can accurately reflect the seismic responses of the HSR piers. Both the moment and shear force time history curves are shown to investigate the force distribution of the HSR piers under earthquakes. Take $10 \mathrm{~m}$ and $22 \mathrm{~m}$ piers as examples, the time history responses of $10 \mathrm{~m}$ pier on site I under the seismic record (Taiwan) and $22 \mathrm{~m}$ pier on site IV under seismic record (Loma Prieta) are shown in Figure 6.

In the Figures 6(a) and 6(b), the moment and shear force of the HSR pier with $10 \mathrm{~m}$ reach the maximum values at the same time of $12.17 \mathrm{sec}$ when the PGA is $0.1 \mathrm{~g}$. When the PGA increases to $1.0 \mathrm{~g}$, the time difference between the maximum moment and shear force is as small as $0.01 \mathrm{sec}$. Figures 6(c) and $6(\mathrm{~d})$ show that the moment and shear of $22 \mathrm{~m}$ pier on site IV reach the maximum values at different time. The maximum moment emerges at $9.51 \mathrm{sec}$, while the maximum shear force occurs at $9.50 \mathrm{sec}$ at $0.1 \mathrm{~g}$ PGA. With PGA increasing to $1.0 \mathrm{~g}$, the time of the maximum moment and shear force is $12.06 \mathrm{sec}$ and $8.19 \mathrm{sec}$, respectively. The changing time demonstrates that the seismic force distribution of the HSR piers is changing as PGA increases. This is because the plastic deformation of the HSR pier has been formed under the strong earthquake.

The Pushover analysis is based on the assumption of the constant seismic force distribution obtained from the first vibration mode of the HSR pier. This means that the Pushover analysis is inapplicable in the seismic analysis of the HSR piers when piers occur with large plastic deformation, because, in this case, it cannot capture the accurate seismic force distribution of the piers.

To better investigate the applicability of Pushover analysis in the seismic analysis of the HSR piers, the effective height 

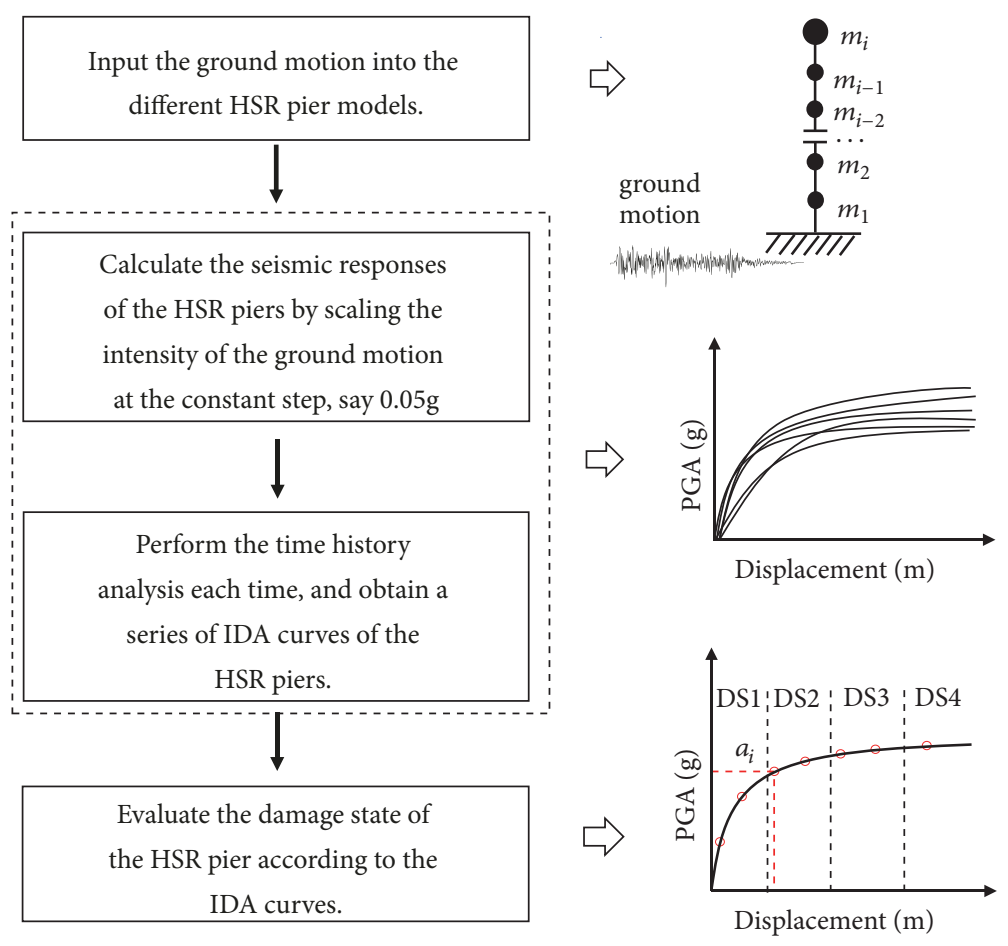

Figure 3: The flowchart of the IDA.

$H_{\text {eff }}$, which is defined as the ratio of the maximum moment to the maximum base shear force calculated by the IDA, is adopted to analyse the change of the seismic force distribution. The effective height ratio $C$ is defined as the ratio of the effective height by IDA to that calculated by the Pushover analysis. They are defined as

$$
\begin{array}{r}
H_{e f f}=\frac{M_{\max }}{F_{\max }}, \\
C=\frac{H_{e f f}}{H}
\end{array}
$$

where $C$ is the ratio of the maximum moment to the maximum base shear force calculated through the IDA and Pushover analysis, respectively. $M_{\max }$ and $F_{\text {max }}$ are the maximum moment and base shear force of the HSR pier, respectively. The effective heights $H_{\text {eff }}$ and effective height ratios $C$ of the HSR piers on the four sites are shown in Figures 7 and 8 , respectively.

Figure 7 shows that the effective height $H_{\text {eff }}$ of the HSR piers by the IDA is reduced with PGA increasing. This demonstrates that the assumption of the constant seismic load distribution in the Pushover analysis is inconsistent with that obtained from the IDA. The inconsistency will lead to the calculation error by the Pushover analysis. In Figure 8, the effective height ratio $C$ is near to 1.0 when PGA is small. However, it decreases as the PGA increases, which has decreased to 0.7 when the PGA is more than $0.4 \mathrm{~g}$. The seismic intensity and pier height have distinct effect on the effective height ratio $C$ of the HSR piers. The effective height ratio $C$ of the lower piers decreases more slowly than that of the high piers. It indicates that the Pushover analysis is more applicable for the lower piers than the high piers. This is because the higher-order vibration modes have distinct effect on the seismic responses of the high pier, which are not considered in the Pushover analysis.

As discussed above, the application of the Pushover analysis into the seismic analysis of the HSR piers is limited. The calculation error by the Pushover analysis will increase as PGA and the height of the HSR piers increases. This is because the seismic load distribution assumed in the Pushover analysis, in fact, is changing in the time history analysis. On the other hand, the influence of higher-order vibration modes of the higher piers are not considered in the Pushover analysis. However, the calculation error by the Pushover analysis is acceptable when the PGA is less than $0.4 \mathrm{~g}$. The fragility probability error of the HSR piers by the Pushover analysis is less than 20\%, and the effective height ratio is above 0.7 compared with that obtained by the IDA. Therefore, the Pushover analysis will be employed as an effective approach to evaluate the seismic performance of the HSR piers and the HSR bridge line in the following part.

\section{Seismic Performance Evaluation of the HSR Piers by the Pushover Analysis}

5.1. Fragility Analysis of the HSR Piers. Several factors, including the pier height and the site, influence the seismic performance of the HSR piers. The fragility curves calculated by (5) are used to describe the seismic performance of the 


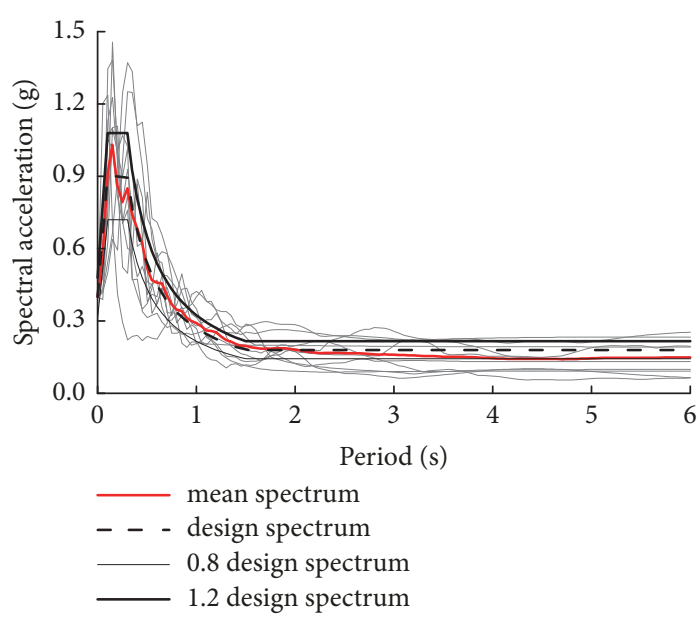

(a) The response spectra on site I

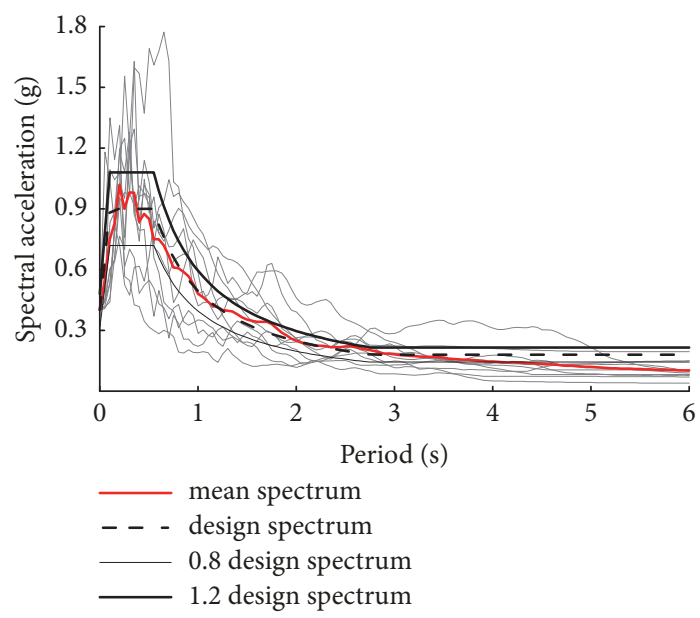

(c) The response spectra on site III

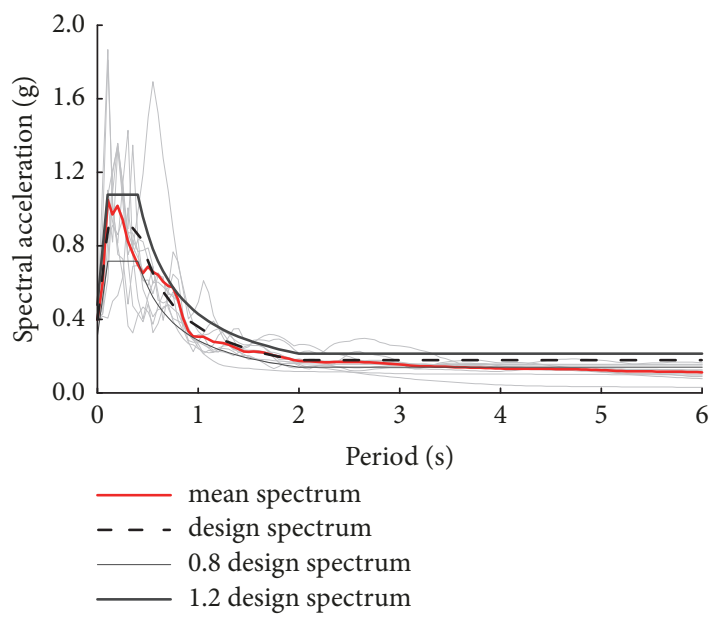

(b) The response spectra on site II

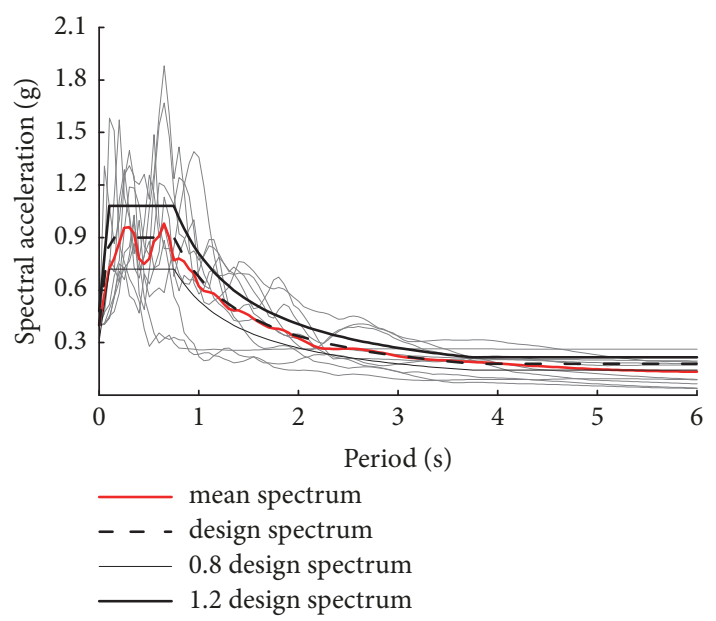

(d) The response spectra on site IV

FIGURE 4: The response spectra of the selected seismic record on four types of sites.

HSR piers with different heights located. Figure 9 shows the fragility probability curves of the HSR piers with $10 \mathrm{~m}, 15 \mathrm{~m}$, $21 \mathrm{~m}$, and $23 \mathrm{~m}$ on site II.

Figures 9(a) and 9(b) show that the slight damage and moderate damage probabilities of $10 \mathrm{~m}, 15 \mathrm{~m}, 21 \mathrm{~m}$, and $23 \mathrm{~m}$ piers are similar. The height of the HSR piers has slight impact on the slight damage and moderate damage probabilities. The $15 \mathrm{~m}$ and $21 \mathrm{~m}$ piers exhibit better seismic performance than the $10 \mathrm{~m}$ and $23 \mathrm{~m}$ piers. Figures $9(\mathrm{c})$ and $9(\mathrm{~d})$ demonstrate that the HSR piers have low damage probabilities at the severe damage and complete damage states. The $10 \mathrm{~m}$ and $15 \mathrm{~m}$ piers are prone to suffer severe and complete damage compared with the $21 \mathrm{~m}$ and $23 \mathrm{~m}$ piers, which indicates the high piers have a better seismic performance. Moreover, the seismic performance of the high piers has been improved with PGA increasing. It is likely that the high piers have larger stiffness, which makes it less fragile to be damaged compared with the lower piers.

The effect of the sites on the seismic fragility of the HSR piers is discussed here. Four types of sites, namely, the rock or hard soil (site I), medium-hard soil (site II), medium-soft soil (site III), and soft soil (site IV), are involved here. The $15 \mathrm{~m}$ pier is taken as a representative for the discussion, as shown in Figure 10.

The four types of sites have the same influence on the seismic performance of the $15 \mathrm{~m}$ pier. The $15 \mathrm{~m}$ pier is the most fragile on soft soil (site IV) but exhibits excellent seismic performance on medium-hard soil (site II). The damage probability of $15 \mathrm{~m}$ pier on hard soil (site I) is lower than that on the medium-soft soil (site III).

5.2. Seismic Performance Evaluation of the HSR Bridge Line. The seismic performance of the HSR bridge line plays a vital role in ensuring the normal operation and the safety of the moving train. The HSR pier, as the core component of the HSR bridge, is adopted to evaluate the seismic performance of the HSR bridge line from the component level. In the Chinese seismic code [26], the bridges are usually designed according to three principles: no structural damage under the low-level 

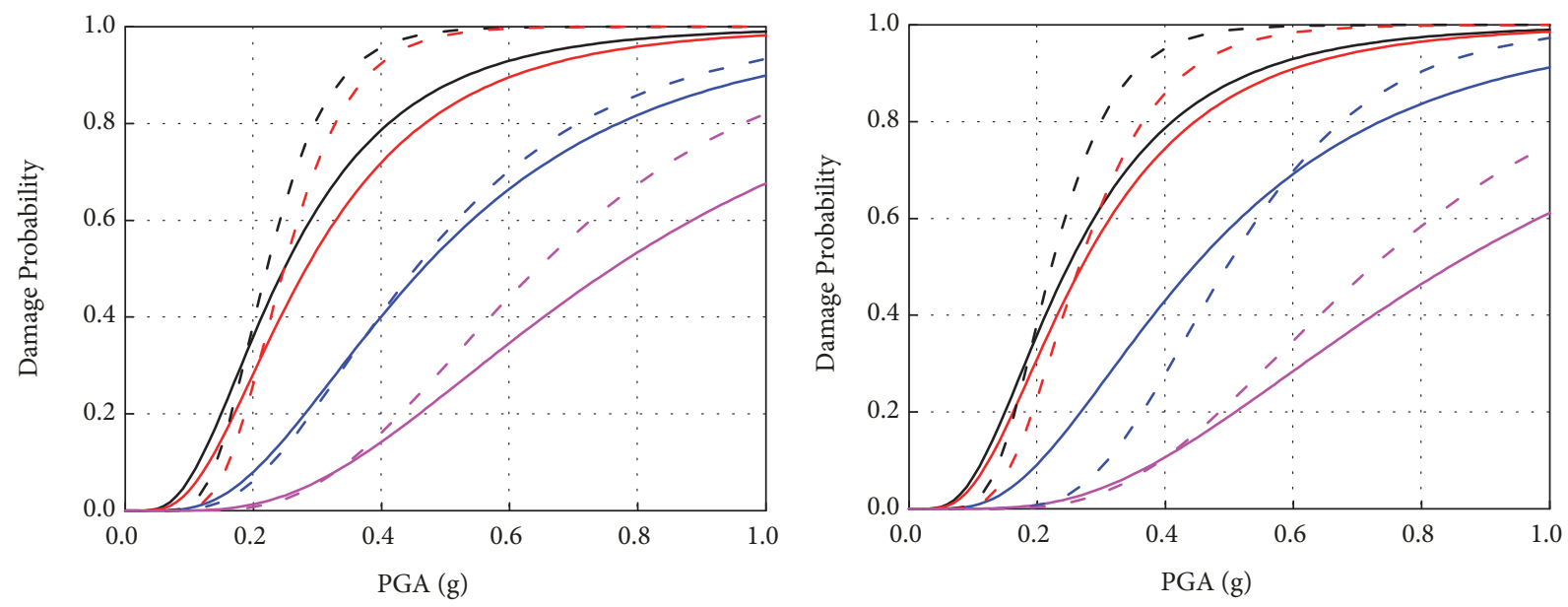

_ slight damage by pushover

_ slight damage by pushover

- - - slight damage by IDA

- moderate damage by pushover

- - - moderate damage by IDA

— severe damage by Pushover

- - - severe damage by IDA

- complete damage by Pushover

- - complete damage by IDA

(a) $10 \mathrm{~m}$

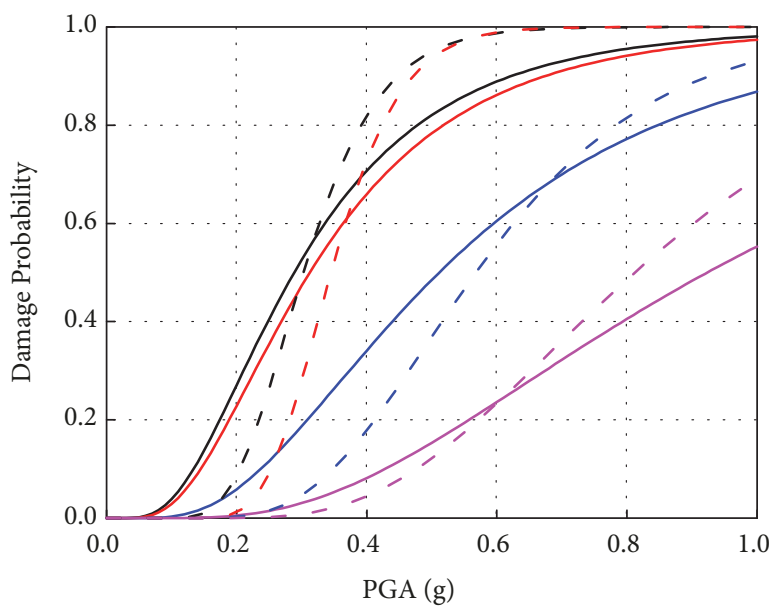

- - - slight damage by IDA

- moderate damage by pushover

- - - moderate damage by IDA

— severe damage by Pushover

- - - severe damage by IDA

— complete damage by Pushover

- - - complete damage by IDA

(b) $12 \mathrm{~m}$

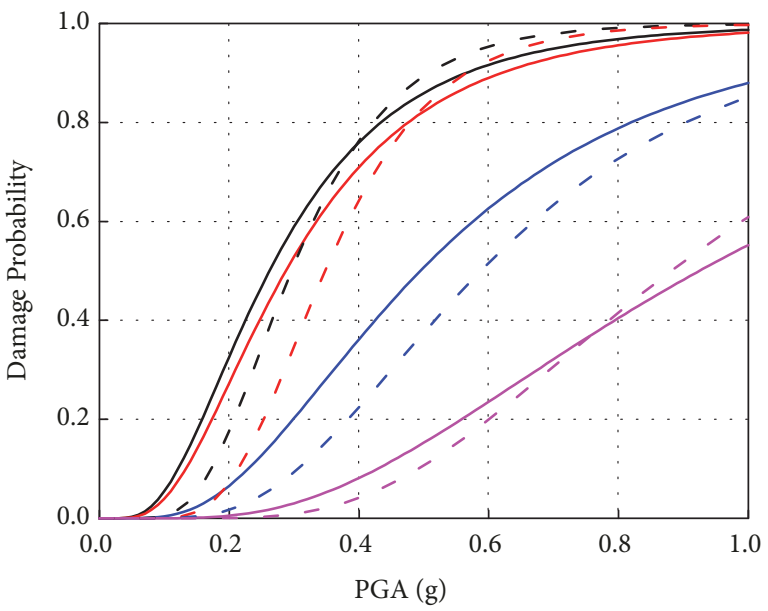

— slight damage by pushover

- - - slight damage by IDA

- moderate damage by pushover

- - - moderate damage by IDA

— severe damage by Pushover

- $\quad$ - $\quad$ severe damage by IDA

_ complete damage by Pushover

- $\quad$ - complete damage by IDA

(c) $15 \mathrm{~m}$

(d) $17 \mathrm{~m}$

Figure 5: Continued. 


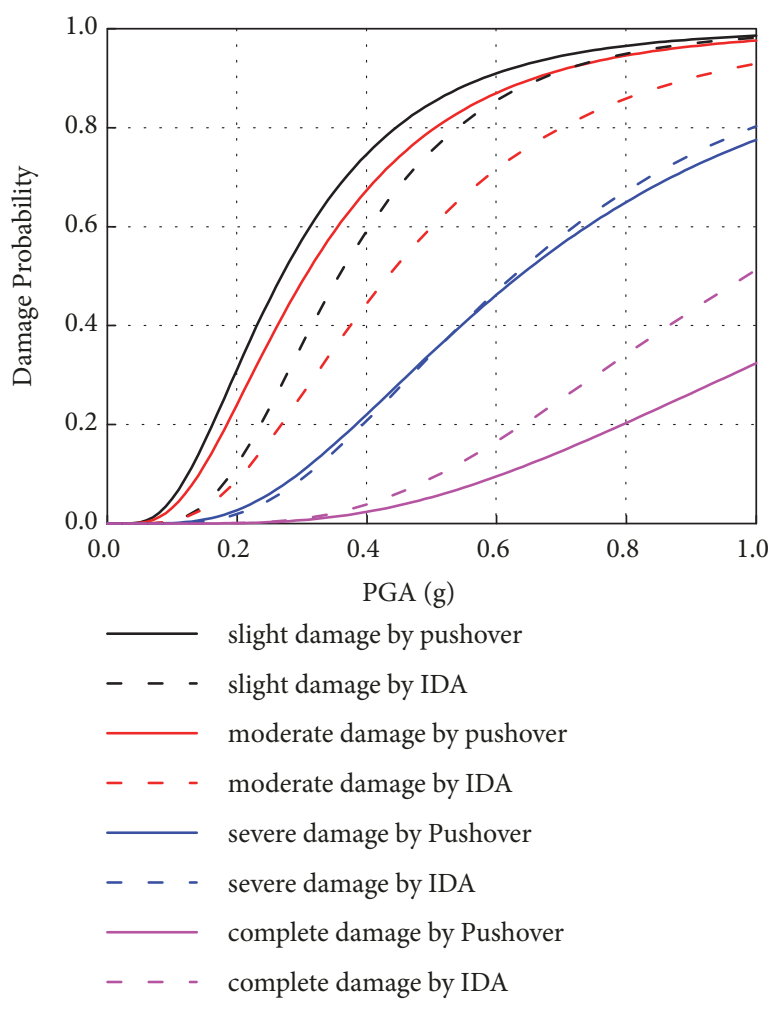

(e) $21 \mathrm{~m}$

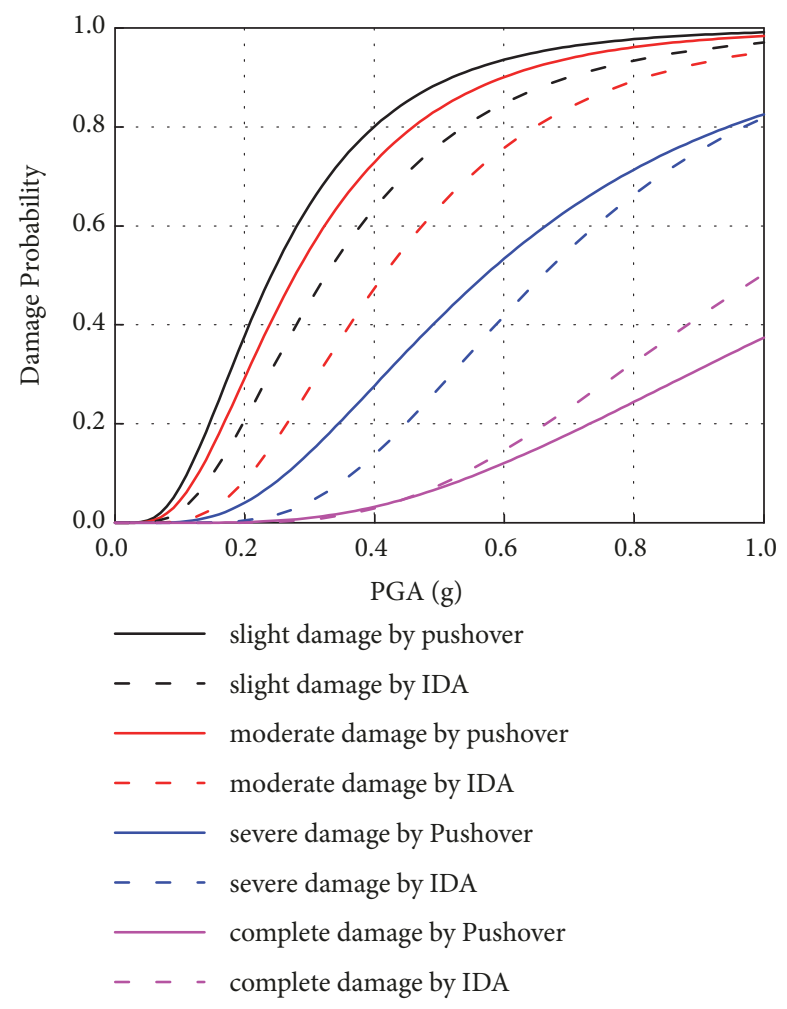

(f) $23 \mathrm{~m}$

Figure 5: Fragility curves of the piers obtained by the Pushover and IDA methods.

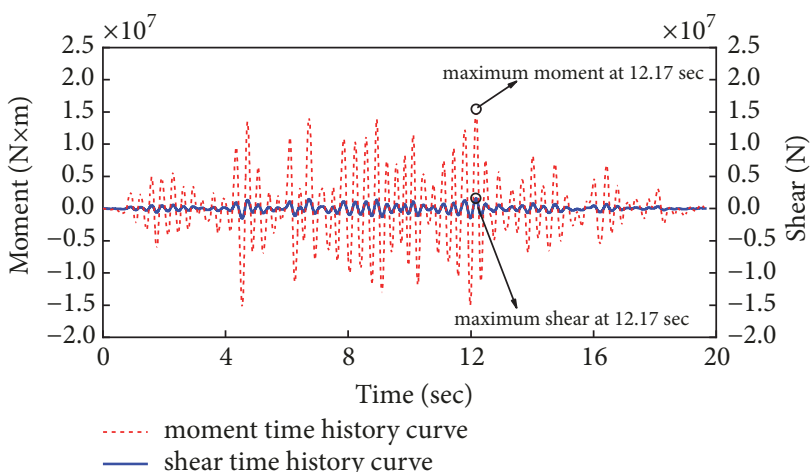

(a) $10 \mathrm{~m}$ pier at $P G A=0.1 \mathrm{~g}$

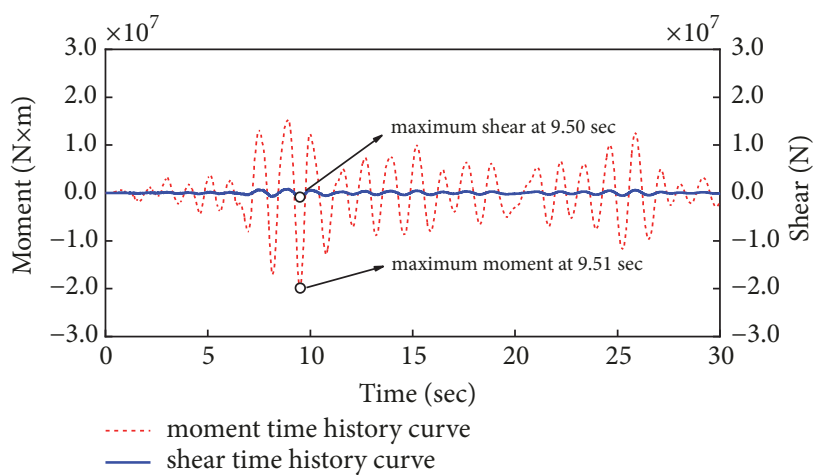

(c) $22 \mathrm{~m}$ pier at $\mathrm{PGA}=0.1 \mathrm{~g}$

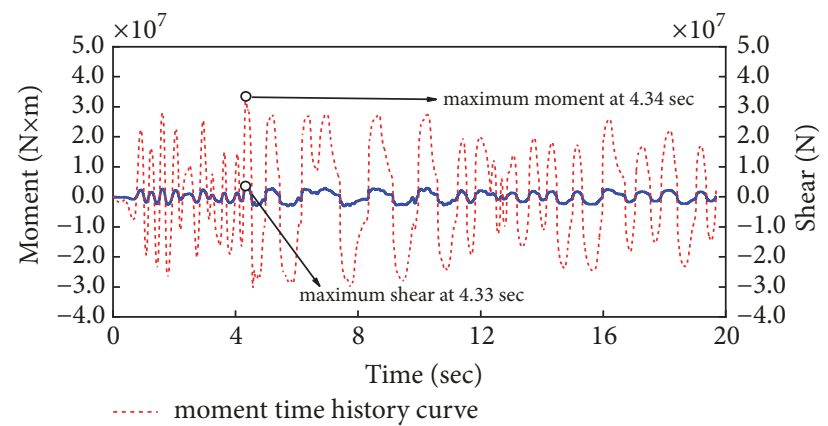

— shear time history curve

(b) $10 \mathrm{~m}$ pier at $P G A=1.0 \mathrm{~g}$

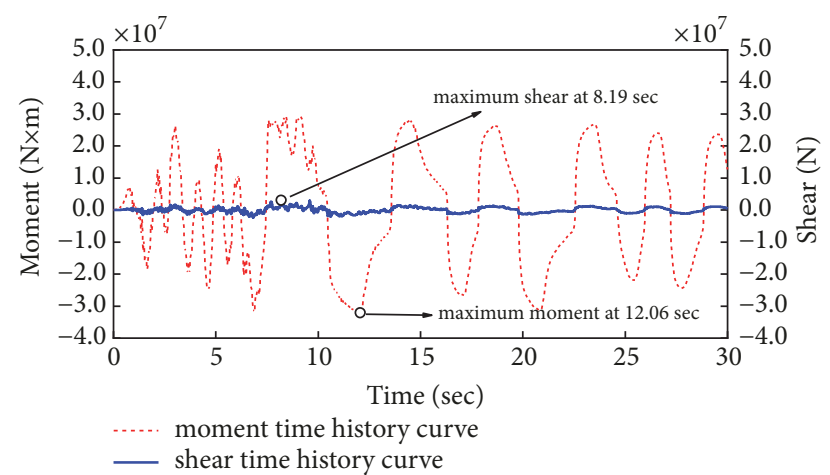

(d) $22 \mathrm{~m}$ pier at $\mathrm{PGA}=1.0 \mathrm{~g}$

FIGURE 6: The time history responses of the HSR piers. 


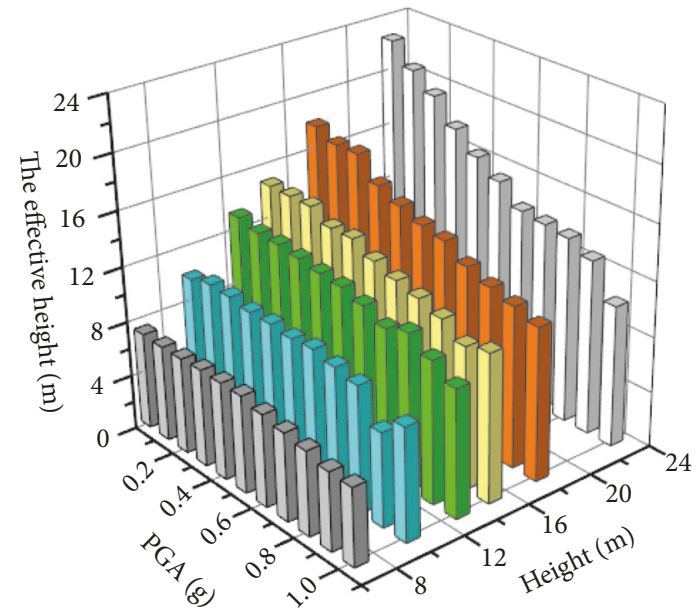

(a) Site I

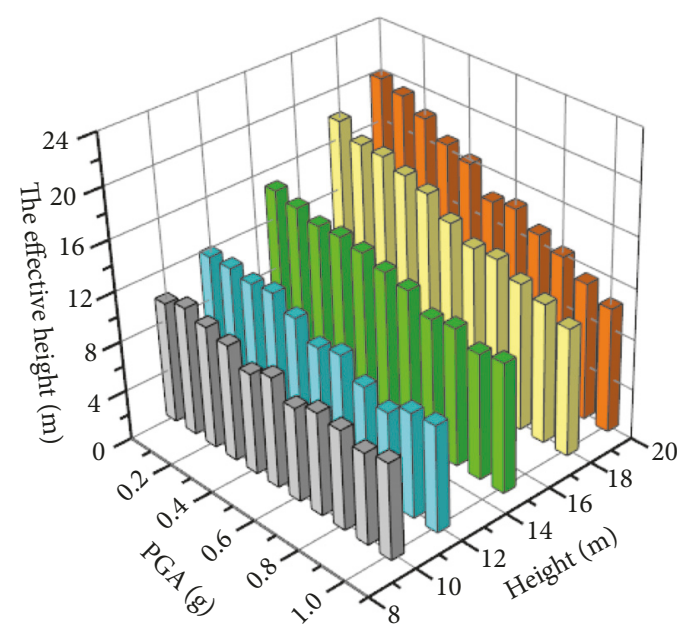

(c) Site III

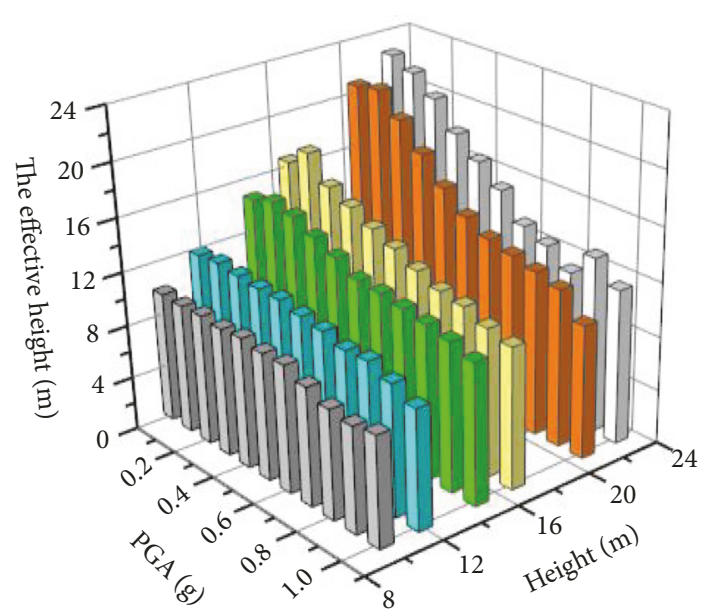

(b) Site II

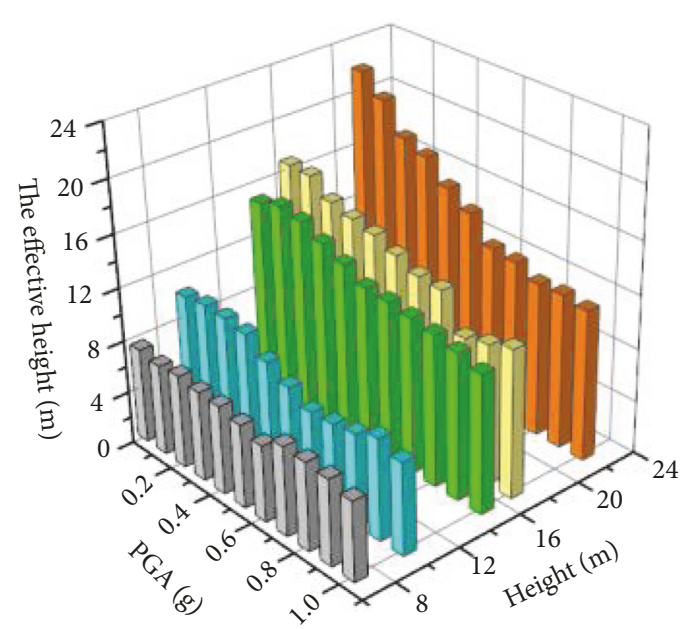

(d) Site IV

FIGURE 7: The effective height of the HSR piers by the IDA.

earthquakes (63\% excessive probability over 50 years), being structurally repairable under the design earthquake $(10 \%$ excessive probability over 50 years), and no collapse during the high-level earthquakes (2 3\% excessive probability over 50 years). To evaluate the seismic performance of the HSR bridge line, the different seismic intensities are involved. They include $0.15 \mathrm{~g}$ PGA for a 7-degree design earthquake, $0.32 \mathrm{~g}$ PGA for the 7-degree high-level earthquake, 0.1 g PGA for the 8-degree low-level earthquake, and $0.4 \mathrm{~g}$ PGA for the 9-degree low-level earthquake [26]. Based on the displacement ductility coefficient index, the seismic performance of the HSR bridge line is evaluated by the Pushover analysis from the component level, as shown in Figure 11.

Figure 11(a) shows that the HSR piers on sites I, II, and III are not damaged, while most of the piers on site IV are moderately damaged under the 7-degree design earthquake (PGA $=0.15 \mathrm{~g})$. The HSR piers on sites I, II, and III almost suffer the moderate damage, while the piers on site IV are severely damaged under the 7-degree rare earthquake $(\mathrm{PGA}=0.32 \mathrm{~g})$, as shown in Figure 11(b). Figure 11(c) demonstrates that all of the HSR piers under the 8-degree low-level earthquake (PGA=0.10 g) are not damaged. In Figure 11(d), the piers on sites I and II are moderately damaged under the 9-degree low-level earthquake ( $P G A=0.40 \mathrm{~g}$ ), and the HSR piers on sites III and IV suffer severe damage. The $10 \mathrm{~m}$ pier on site IV is completely damaged. The seismic performance of the HSR bridge line, designed by the 7degree design earthquake ( $P G A=0.15 \mathrm{~g}$ ), can satisfy the seismic requirements in Chinese seismic code. The HSR bridge line has good seismic performance under the 7degree design earthquake $(0.15 \mathrm{~g})$ and 8 -degree low-level earthquake $(0.10 \mathrm{~g})$ from the perspective of the structural safety. However, the HSR bridge line is likely to be severely damaged even under the 9-degree low-level earthquake $(0.40 \mathrm{~g})$. Therefore, the seismic design of the HSR piers should be improved. 


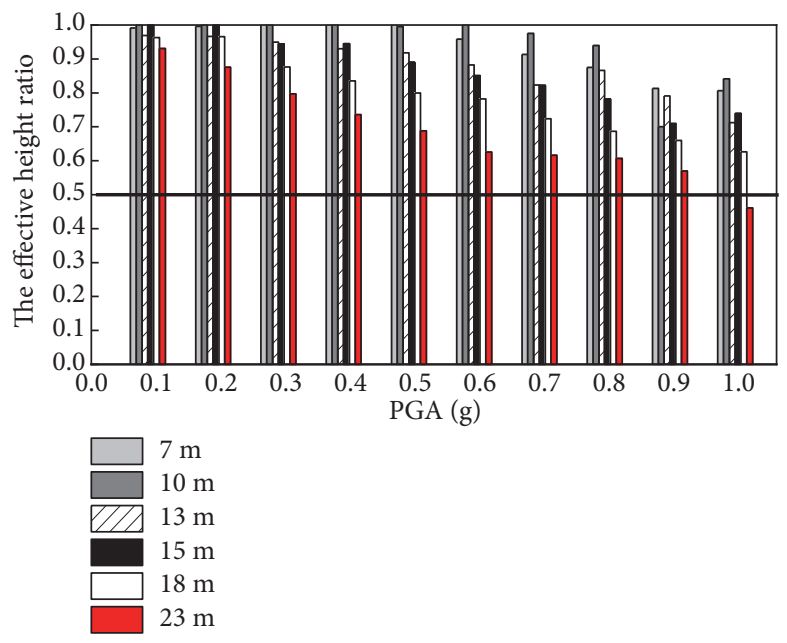

(a) The effective height ratio of the HSR piers on site I

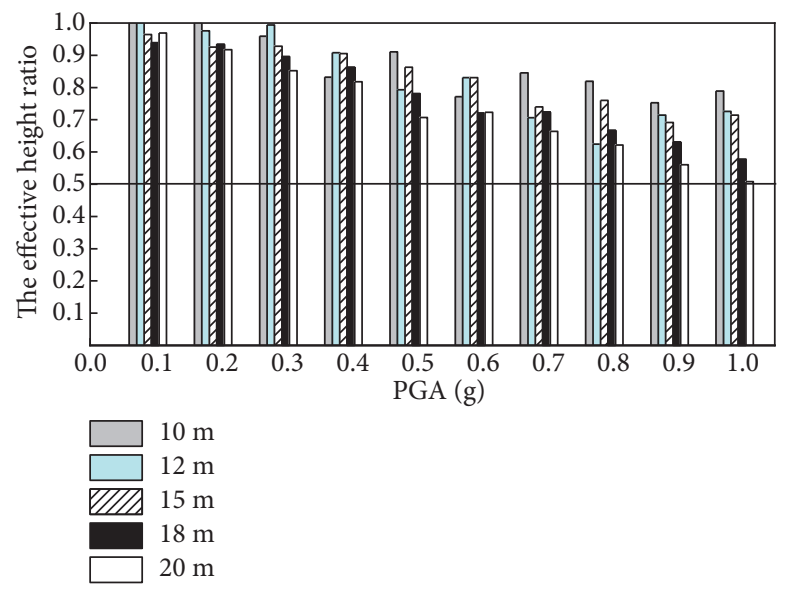

(c) The effective height ratio of the HSR piers on site III

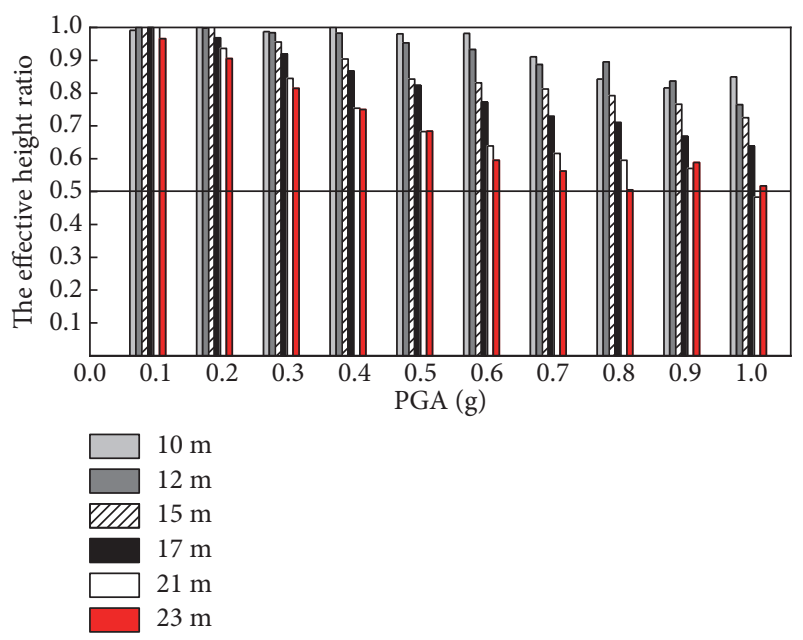

(b) The effective height ratio of the HSR piers on site II

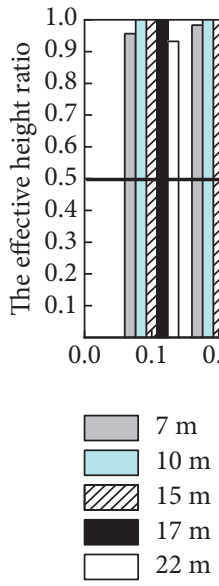

(d) The effective height ratio of the HSR piers on site IV

FIgURE 8: The effective height ratio of the HSR piers on the four types of site.

\section{Discussion}

This paper extends the application of the Pushover analysis into the seismic performance evaluation of the HSR piers. In the previous literatures, the applicability of the Pushover analysis in the seismic evaluation of the structures such as the ordinary bridge [40], underground structures [23], and buildings [41] has been well investigated. However, there is limited research on the applicability of the Pushover analysis on the seismic performance evaluation for HSR. The Pushover analysis presents the computational attractiveness and effectiveness for the seismic analysis of the HSR piers. This paper provides a practical-oriented approach for the seismic performance evaluation of the HSR bridge line.

The HSR piers are the resisting components, which is recommendable for the seismic analysis in the current HSR seismic code [26]. The high HSR pier exhibits better seismic performance than the lower pier. This is consistent with the experiment of the HSR piers by the low cycle test [11].

The Pushover analysis was adopted to evaluate the seismic performance of the HSR bridge line from the component level. The seismic performance of the five-span HSR bridge [42] demonstrates that the HSR bridge has a good seismic performance with sufficient ductility ability under the strong earthquake. However, the HSR bridge line exhibits inadequate antiseismic ability under the 9-degree low-level earthquake $(0.40 \mathrm{~g})$.

\section{Conclusions}

In this paper, the finite element models of the HSR piers are established by OpenSees. The Pushover analysis and IDA are applied into the seismic analysis of the HSR pier. The calculation error by the Pushover analysis is discussed. Based on the displacement ductility coefficient index, the Pushover analysis is adopted to evaluate the fragility of the 


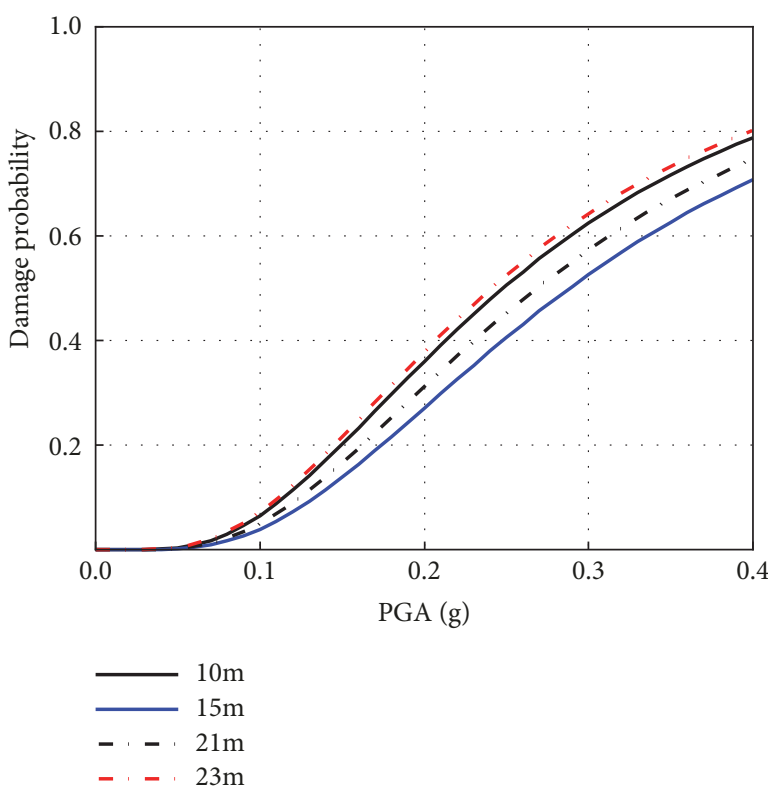

(a) Slight damage
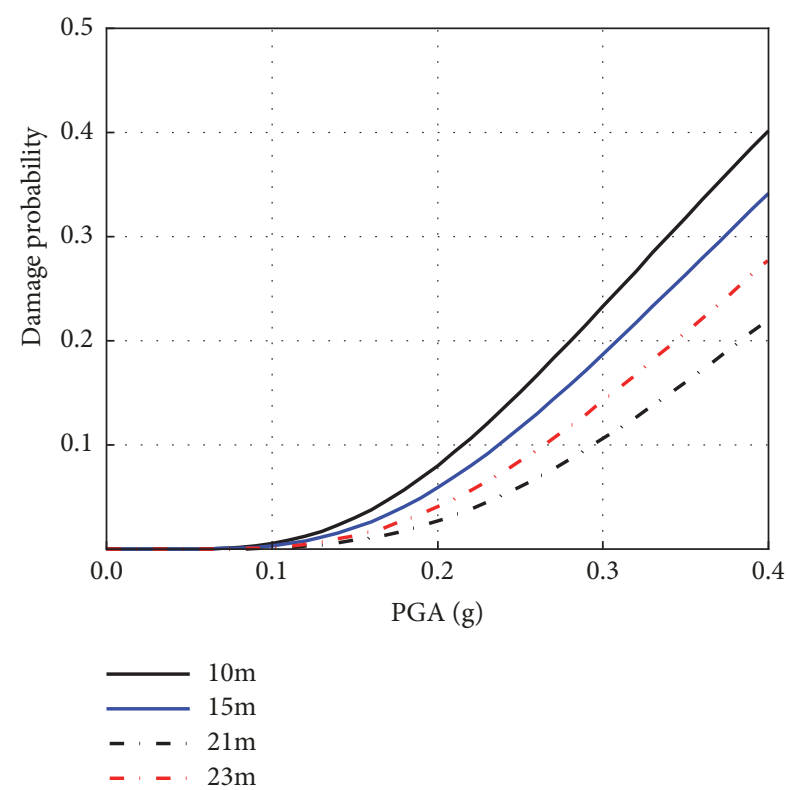

(c) Severe damage

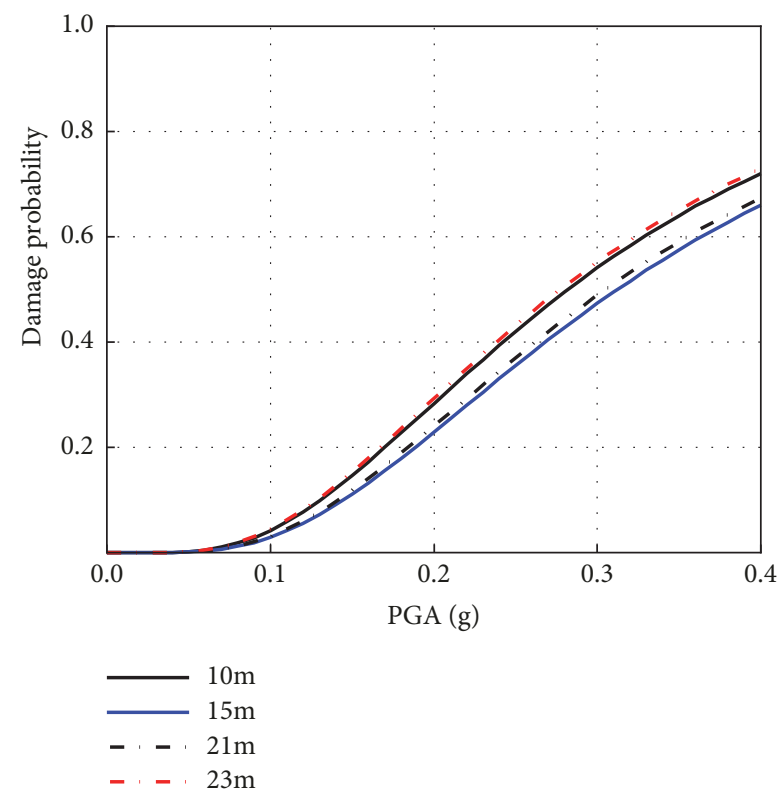

(b) Moderate damage

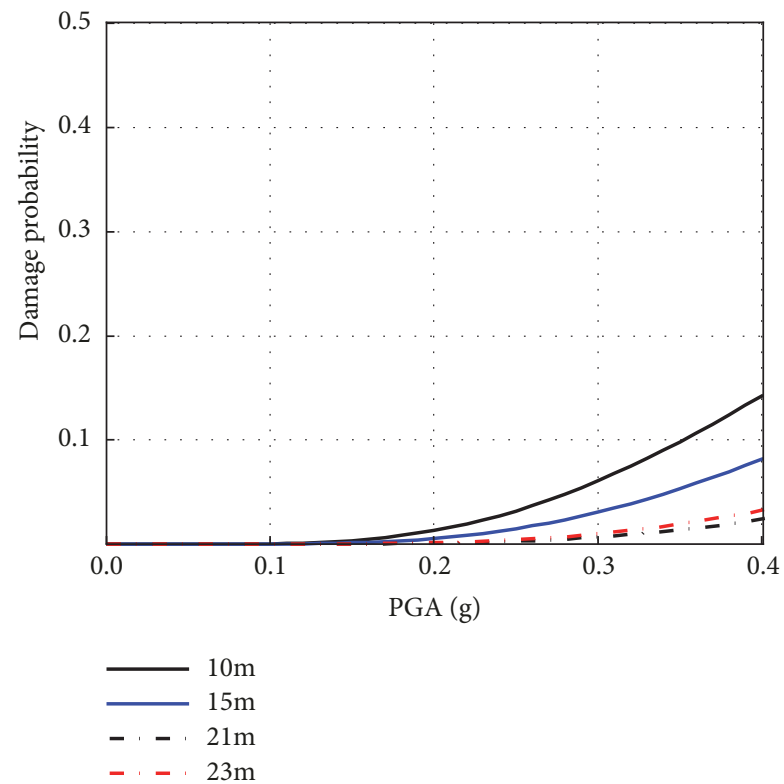

(d) Complete damage

FIGURE 9: The fragility curves of HSR piers on site II.

HSR piers and the seismic performance of the HSR bridge line from the component level. Some conclusions are given as follows:

(1) The Pushover analysis is an attractive approach for the seismic analysis of the HSR piers. the Pushover analysis is computationally effective within the acceptable calculation error for the seismic performance of the HSR piers when PGA is less than $0.4 \mathrm{~g}$.

(2) The damage probabilities of piers are slightly different under slight damage and moderate damage states. The high piers (e.g., $21 \mathrm{~m}$ pier) have better seismic performance than the low piers (e.g., 10-m pier) under severe damage and complete damage states.

(3) The fragility analysis of the HSR piers on the four types of site indicates that the piers on site II have the lowest damage probability while piers on site IV are the most seismically fragile.

(4) From the component level, the HSR bridge line can satisfy the seismic demands of the Chinese seismic code under the 7-degree design earthquake ( $P G A=0.15 \mathrm{~g})$ and 

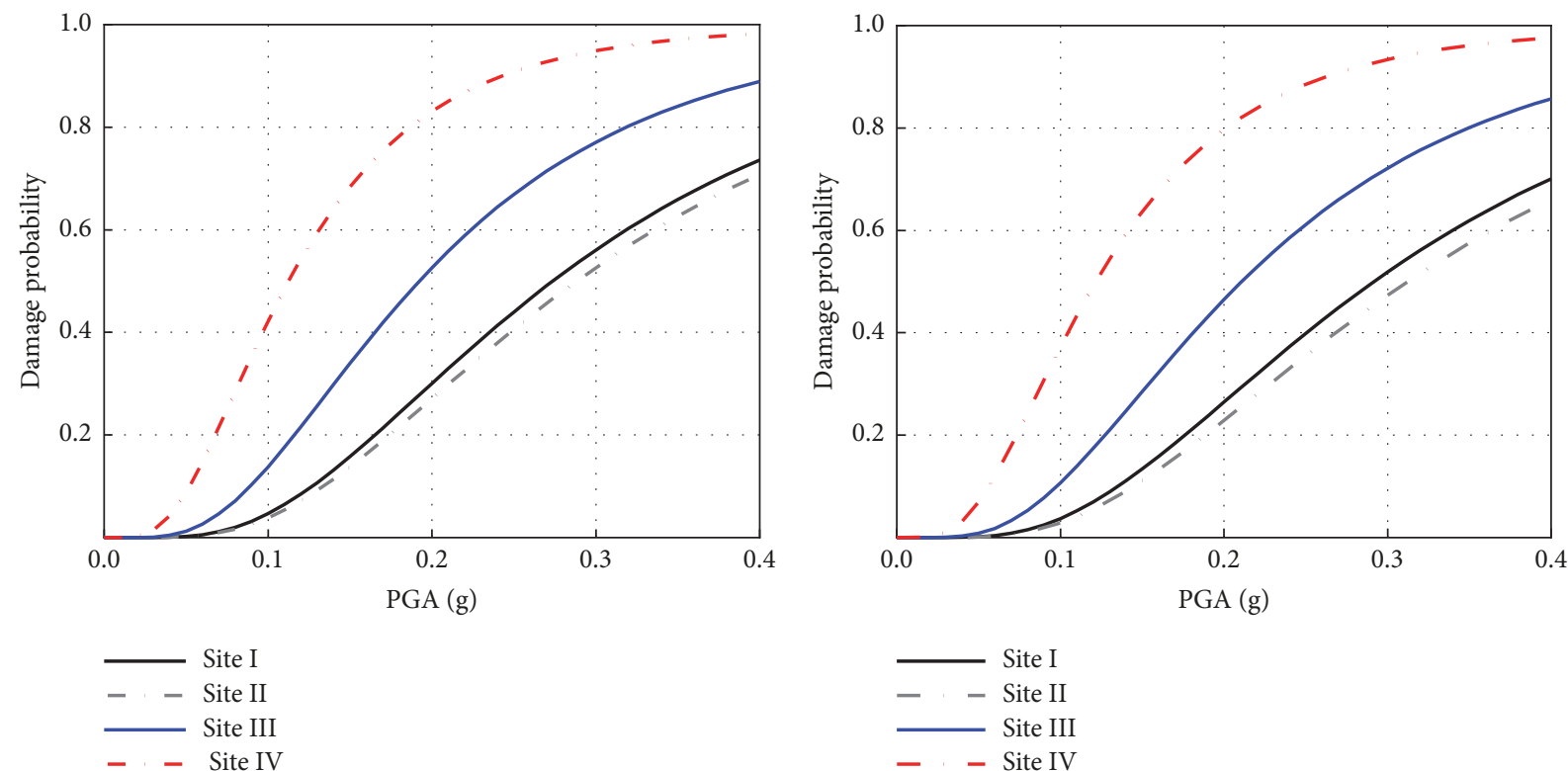

(a) Slight damage

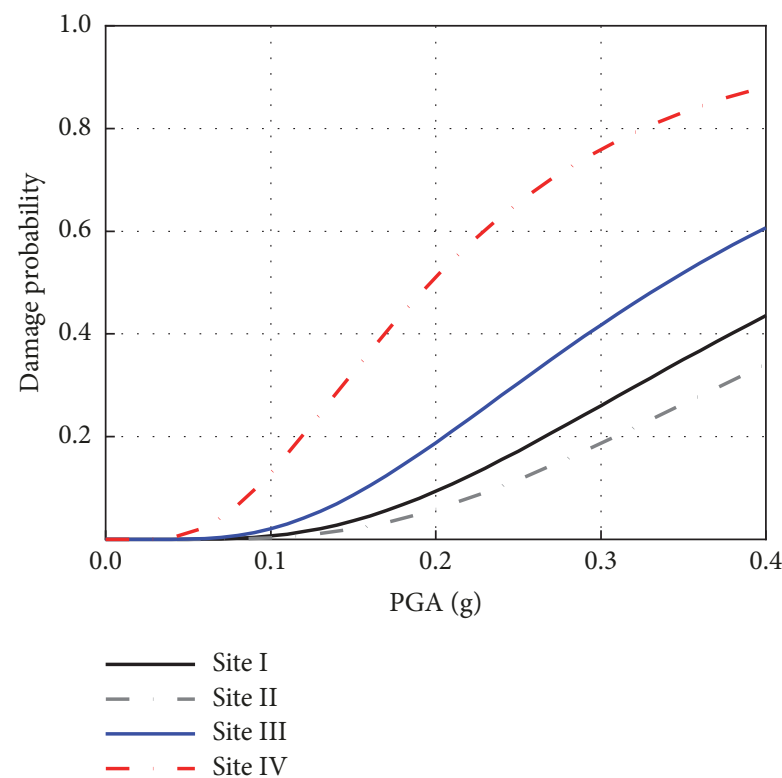

(c) Severe damage

(b) Moderate damage

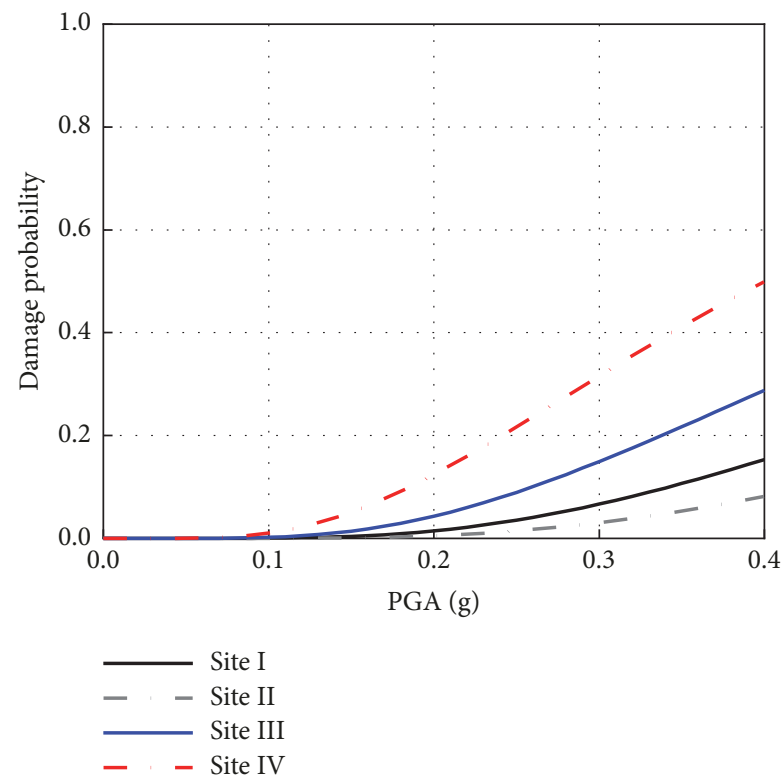

(d) Complete damage

FIgURE 10: The fragility curves of the $15 \mathrm{~m}$ piers on the four different types of sites.

8-degree low-level earthquake (PGA=0.10 g). However, the HSR bridge line is likely to be severely damaged under the 9-degree low-level earthquake (PGA=0.40 g). The seismic design of HSR bridge line should be improved.

\section{Data Availability}

The data used to support the findings of this study may be released upon application to the authors, who can be contacted atguowei@csu.edu.cn.

\section{Conflicts of Interest}

The authors declare that they have no conflicts of interest.

\section{Acknowledgments}

This research is supported by the Fundamental Research Funds for the Central Universities of Central South University [Project No. 502221804], the National Natural Science Foundation of China [Project Nos. 51878674, 51878563], 


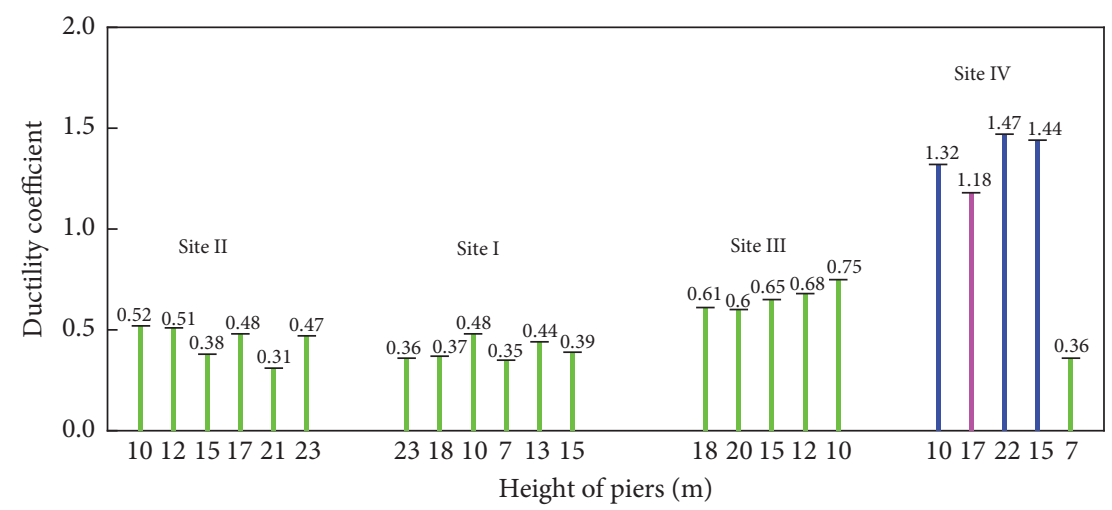

$10 \mathrm{~m} 12 \mathrm{~m} \quad 15 \mathrm{~m} \quad 17 \mathrm{~m} \quad 21 \mathrm{~m} \quad 23 \mathrm{~m} \quad 23 \mathrm{~m} \quad 18 \mathrm{~m} \quad 10 \mathrm{~m} \quad 7 \mathrm{~m} \quad 13 \mathrm{~m} \quad 15 \mathrm{~m} \quad 18 \mathrm{~m} \quad 20 \mathrm{~m} \quad 15 \mathrm{~m} \quad 12 \mathrm{~m} \quad 10 \mathrm{~m} \quad 10 \mathrm{~m} \quad 17 \mathrm{~m} \quad 22 \mathrm{~m} \quad 15 \mathrm{~m} \quad 7 \mathrm{~m}$

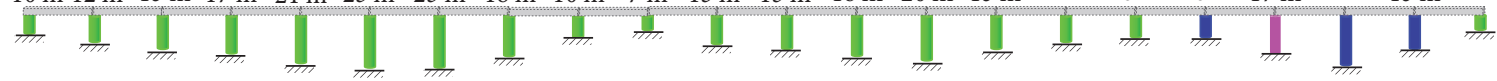

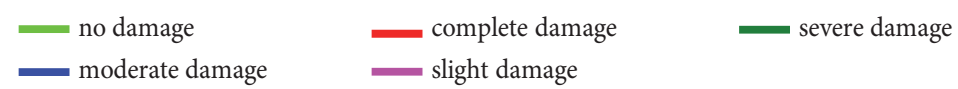

(a) The seismic performance of the HSR bridge line under the 7-degree design earthquake $(0.15 \mathrm{~g})$

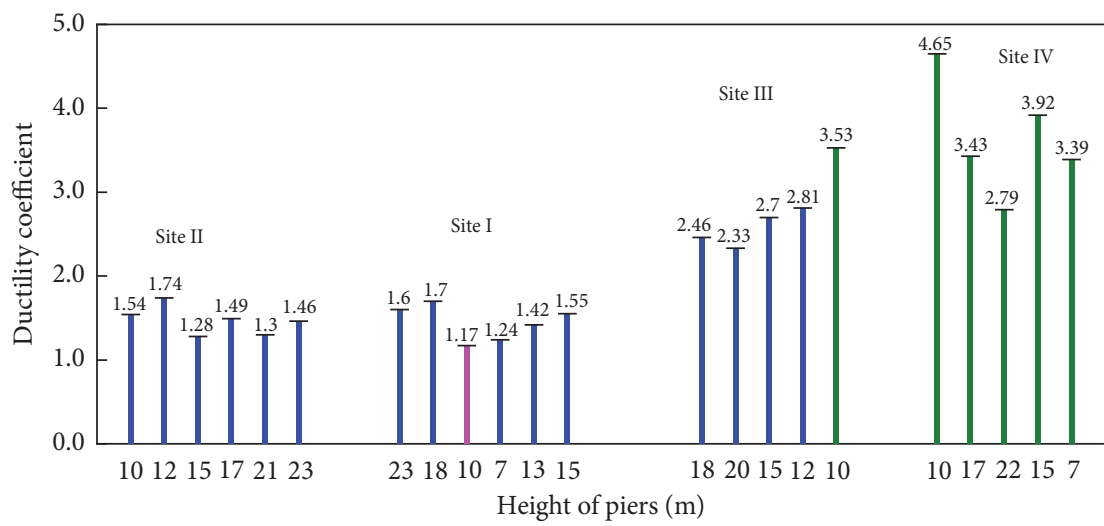

$10 \mathrm{~m} \quad 12 \mathrm{~m} \quad 15 \mathrm{~m} \quad 17 \mathrm{~m} \quad 21 \mathrm{~m} \quad 23 \mathrm{~m} \quad 23 \mathrm{~m} \quad 18 \mathrm{~m} \quad 10 \mathrm{~m} \quad 7 \mathrm{~m} \quad 13 \mathrm{~m} \quad 15 \mathrm{~m} \quad 18 \mathrm{~m} \quad 20 \mathrm{~m} \quad 15 \mathrm{~m} \quad 12 \mathrm{~m} \quad 10 \mathrm{~m} \quad 10 \mathrm{~m} \quad 17 \mathrm{~m} \quad 22 \mathrm{~m} \quad 15 \mathrm{~m} \quad 7 \mathrm{~m}$

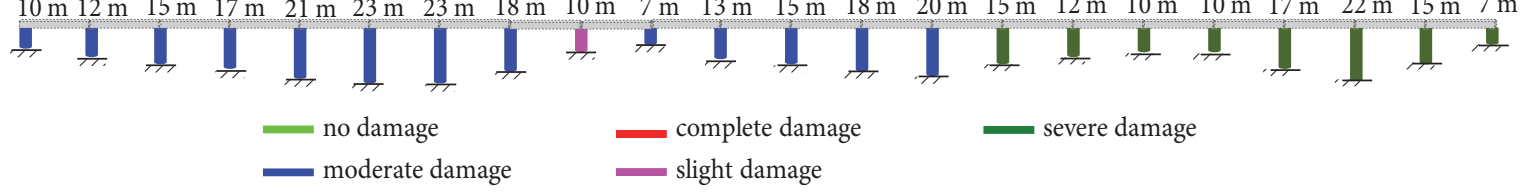

(b) The seismic performance of the HSR bridge line under the 7-degree high-level earthquake $(0.32 \mathrm{~g})$

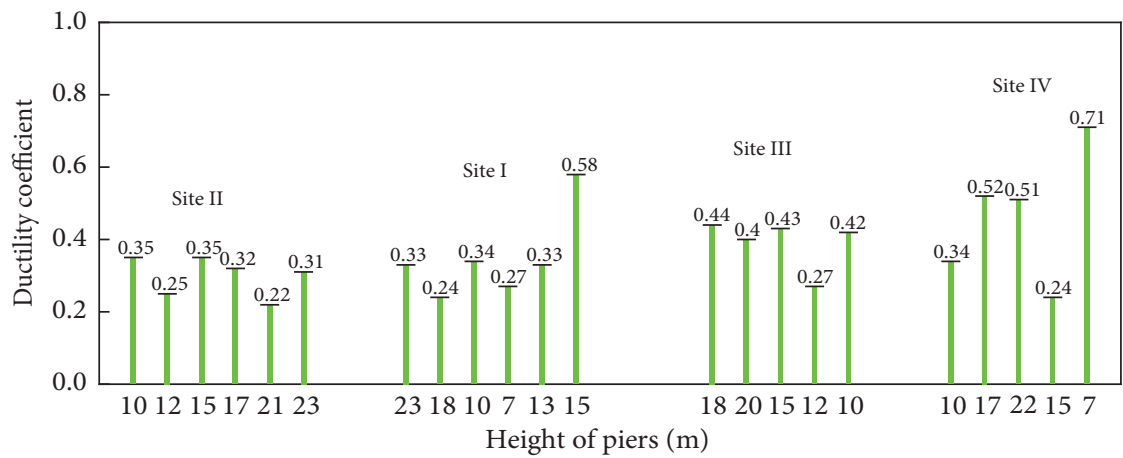

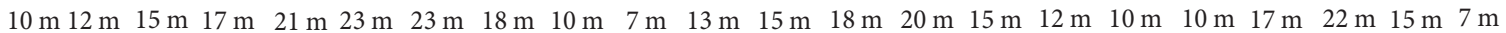

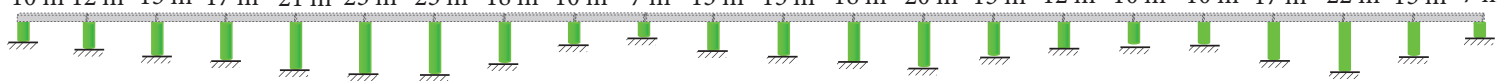

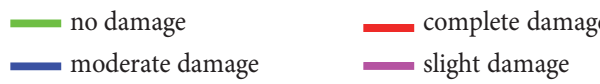

(c) The seismic performance of the HSR bridge line under the 8-degree low-level earthquake $(0.10 \mathrm{~g})$

FIGURE 11: Continued. 


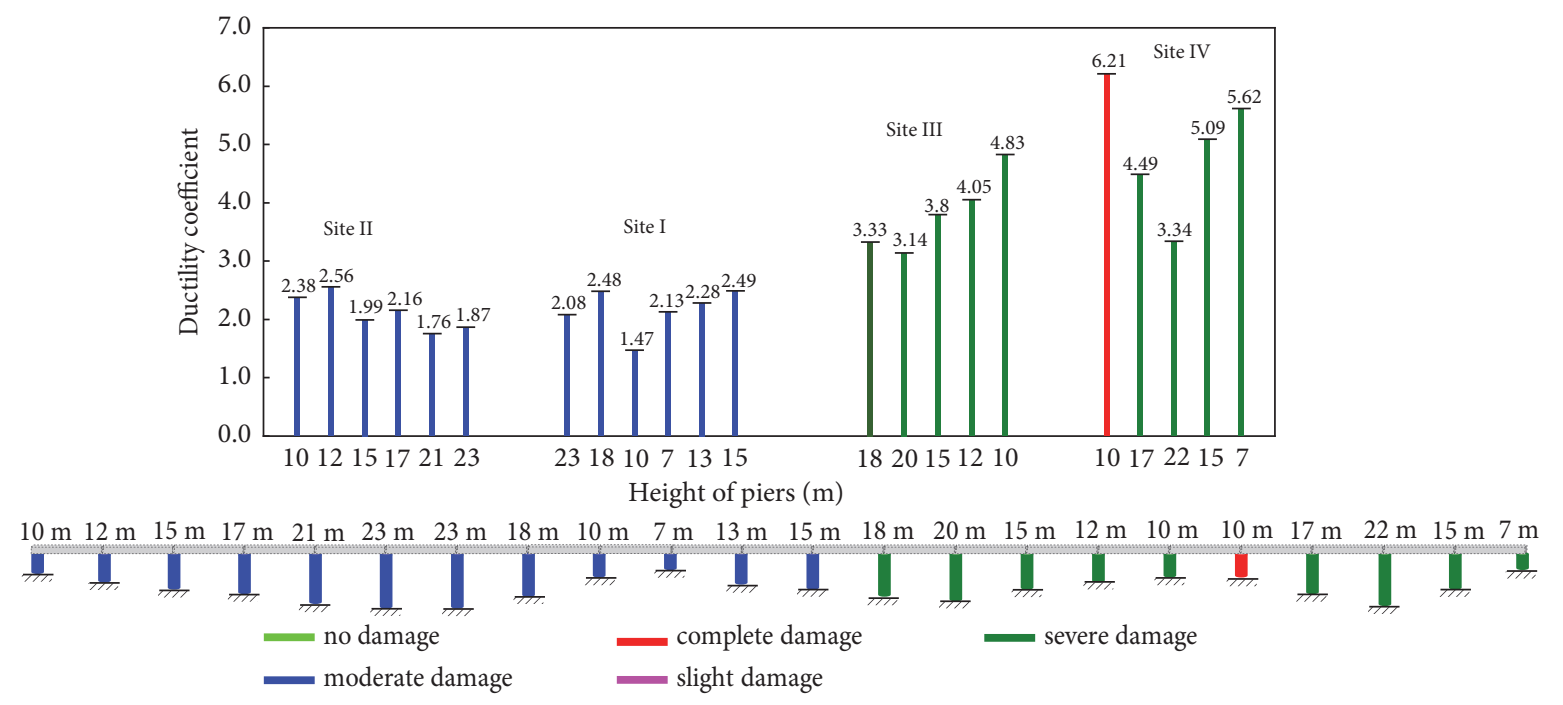

(d) The seismic performance of the HSR bridge line under the 9-degree low-level earthquake ( $0.40 \mathrm{~g})$

FIGURE 11: The seismic performance evaluation of the HSR bridge line.

the Foundation for Key Youth Scholars in Hunan Province [Project No. 150220077], and the Project of Yuying Plan in Central South University [Project No. 502034002].

\section{References}

[1] B. Yan, G.-L. Dai, and N. Hu, "Recent development of design and construction of short span high-speed railway bridges in China," Engineering Structures, vol. 100, pp. 707-717, 2015.

[2] X. He, T. Wu, Y. Zou, Y. F. Chen, H. Guo, and Z. Yu, "Recent developments of high-speed railway bridges in China," Structure and Infrastructure Engineering, vol. 13, no. 12, pp. 112, 2017.

[3] A. Kuriqi, M. Ardiçlioglu, and Y. Muceku, "Investigation of seepage effect on river dike's stability under steady state and transient conditions," Pollack Periodica, vol. 11, no. 2, pp. 87-104, 2016.

[4] Y. Muceku, O. Korini, and A. Kuriqi, "Geotechnical analysis of hill's slopes areas in heritage town of berati, Albania," Periodica Polytechnica Civil Engineering, vol. 60, no. 1, pp. 61-73, 2016.

[5] N. Hu, G. Dai, B. Yan, and K. Liu, "Recent development of design and construction of medium and long span high-speed railway bridges in China," Engineering Structures, vol. 74, pp. 233-241, 2014.

[6] S. Qin and Z. Gao, "Developments and prospects of long-span high-speed railway bridge technologies in China," Engineering Journal, vol. 3, no. 6, pp. 787-794, 2017.

[7] W. P. Yen, G. Chen, M. Yashinski et al., "Lessons in bridge damage learned from the Wenchuan earthquake," Earthquake Engineering and Engineering Vibration, vol. 8, no. 2, pp. 275$285,2009$.

[8] G. H. Zhao and Y. M. Zhang, "Analysis on earthquake damage of daxinglu ramp bridge in wenchuan earthquake," Advanced Materials Research, vol. 255-260, pp. 1003-1006, 2011.

[9] K. Kawashima, S. Unjoh, J. Hoshikuma, and K. Kosa, "Damage of bridges due to the 2010 maule, Chile, Earthquake," Journal of Earthquake Engineering, vol. 15, no. 7, pp. 1036-1068, 2011.
[10] X. L. Du, Q. Han, and Z. X. Li, "Earthquake damage and revelation of 5.12 Wenchuan seismic zhongshan highway bridge," Journal of Beijing University of Technology, vol. 34, no. 12, pp. 1270-1279, 2008.

[11] G. Shao, L. Jiang, and N. Chouw, "Experimental investigations of the seismic performance of bridge piers with rounded rectangular cross-sections," Earthquake and Structures, vol. 7, no. 25, pp. 463-484, 2014.

[12] L. K. Chen, L. Z. Jiang, and P. Liu, "Seismic response analyses of high-speed railway bridge round-ended piers using global bridge model," International Journal of Materials and Product Technology, vol. 44, no. 1-2, pp. 35-46, 2012.

[13] L. Chen, "Analysis of elastoplastic seismic response of highspeed railway bridge with round-ended piers," Journal of South China University of Technology (Natural Science Edition), vol. 39, no. 6, pp. 126-131, 2011.

[14] L. K. Chen, L. Z. Jiang, Z. P. Zeng, and B. F. Luo, "Seismic response analysis of high-speed railway bridge fabricated round-ended piers," Advanced Materials Research, vol. 243-249, pp. 3844-3847, 2011.

[15] S. Ghosh, S. Ghosh, and S. Chakraborty, "Seismic fragility analysis in the probabilistic performance-based earthquake engineering framework: an overview," International Journal of Advances in Engineering Sciences and Applied Mathematics, pp. $1-14,2017$.

[16] Z. Lu, T. Usami, and H. Ge, "A simplified seismic performance evaluation procedure for steel arch bridges," IABSE Symposium Report, vol. 88, no. 8, pp. 94-99, 2004.

[17] A. Muntasir Billah and M. Shahria Alam, "Seismic fragility assessment of highway bridges: a state-of-the-art review," Structure and Infrastructure Engineering, vol. 11, no. 6, pp. 804-832, 2014.

[18] Q. Wang, Z. Wu, and S. Liu, "Seismic fragility analysis of highway bridges considering multi-dimensional performance limit state," Earthquake Engineering and Engineering Vibration, vol. 11, no. 2, pp. 185-193, 2012.

[19] Y. Zhang, P. Tan, J.-X. Zheng, and F.-L. Zhou, "Fragility analysis for performance-based seismic design of prefabricated bridge 
with middle-small span," Zhendong Gongcheng Xuebao, vol. 27, no. 5, pp. 676-684, 2014.

[20] B. G. Nielson and R. DesRoches, "Seismic fragility methodology for highway bridges using a component level approach," Earthquake Engineering \& Structural Dynamics, vol. 36, no. 6, pp. 823-839, 2007.

[21] J. Dong, D. Shan, and E. Zhang, "Seismic fragility of continuous rigid frame bridge with unequal pier height," IABSE Symposium Report, vol. 103, no. 2, pp. 234-242, 2015.

[22] H. Krawinkler and G. D. P. K. Seneviratna, "Pros and cons of a pushover analysis of seismic performance evaluation," Engineering Structures, vol. 20, no. 4-6, pp. 452-464, 1998.

[23] J. Liu, W. Wang, and G. Dasgupta, "Pushover analysis of underground structures: Method and application," Science China Technological Sciences, vol. 57, no. 2, pp. 423-437, 2014.

[24] M. Shinzuka, M. Q. Feng, and H. K. Kim, "Nonlinear static procedure for fragility curves development," Journal of Engineering Mechanics, vol. 126, no. 12, pp. 1287-1296, 2000.

[25] S. Banerjee and M. Shinozuka, "Nonlinear static procedure for seismic vulnerability assessment of bridges," Computer-Aided Civil and Infrastructure Engineering, vol. 22, no. 4, pp. 293-305, 2007.

[26] GB500111, Code for Seismic Design of Railway Engineering, China Planning Press, Beijing, China, 2009.

[27] JTG/TB02-01, Guidelines for Seismic Design of Highway Bridges, China Communications Press, Beijing, China, 2008.

[28] L.-Z. Jiang, G.-Q. Shao, H. Wang, and J.-J. Jiang, "Experimental study on seismic performance of hollow piers with rounded rectangular cross section in high-speed railways," Engineering Mechanics, vol. 31, no. 3, pp. 72-82, 2014 (Chinese).

[29] H. Hwang, J. B. Liu, and Y. H. Chiu, "Seismic fragility analysis of highway bridges," Tech. Rep., Center for Earthquake Research and Information, The University of Memphis, 2001.

[30] ATC-40, Seismic Evaluation and Retrofit of Concrete Buildings Volume 1, Applied Technology Council, Redwood City, USA, 1996.

[31] J. Sun, O. Tetsuro, Y. Zhao, and W. Wang, "Lateral load pattern in pushover analysis," Earthquake Engineering and Engineering Vibration, vol. 2, no. 1, pp. 99-107, 2003.

[32] Z. Shanwen and W. Xiuxin, "Effects of Pushover analysis load patterns on seismic responses of the circular double-column piers," Earthquake Engineering \& Engineering Dynamics, vol. 35, no. 3, pp. 94-99, 2015 (Chinese).

[33] G. Augusti, "Dynamics of structures: theory and applications to earthquake engineering," Meccanica, vol. 31, no. 6, pp. 968-968, 1996.

[34] Y. Y. Lin and K. C. Chang, "Effects of site classes on damping reduction factors," Journal of Structural Engineering, vol. 130, no. 11, pp. 1667-1675, 2004.

[35] Y. Y. Lin, E. Mirand, and K. C. Chang, "Evaluation of damping reduction factors for estimating elastic response of structures with high damping," Earthquake Engineering \& Structural Dynamics, vol. 34, no. 11, pp. 1427-1443, 2005.

[36] D. Vamvatsikos and C. A. Cornell, "Applied incremental dynamic analysis," Earthquake Spectra, vol. 20, no. 2, pp. 491514, 2004

[37] B. Chiou, R. Darragh, N. Gregor, and W. Silva, "NGA project strong-motion database," Earthquake Spectra, vol. 24, no. 1, pp. 23-44, 2008.

[38] A. Kappos, I. Moshonas, T. Paraskeva, and A. Sextos, "A methodology for deviation of seismic fragility curves for bridges with the aid of advanced analysis tools," in Proceedings of the 13th ECEE \& 30th General Assembly of the ESC, Geneva, Switzerland, 2007.

[39] F. Zareian and H. Krawinkler, "Assessment of probability of collapse and design for collapse safety," Earthquake Engineering \& Structural Dynamics, vol. 36, no. 13, pp. 1901-1914, 2007.

[40] Y. Gu and W. Zhuo, "Study on applicability of a pushover analysis method for seismic analysis of long-span continuous rigid frame bridge with high piers," Journal of Computational \& Theoretical Nanoscience, vol. 9, pp. 729-734, 2012.

[41] K. Huang and J. S. Kuang, "On the applicability of pushover analysis for seismic evaluation of medium-and high-rise buildings," The Structural Design of Tall and Special Buildings, vol. 19, no. 5, pp. 573-588, 2010.

[42] Y. L. Zhang, J. F. Sun, and J. L. Xu, "Analysis of seismic response and seismic checking in a long-span continuous beam bridge on a high-speed railway," China Erathquake Engineering Journal, no. 2, pp. 226-231, 2013 (Chinese). 


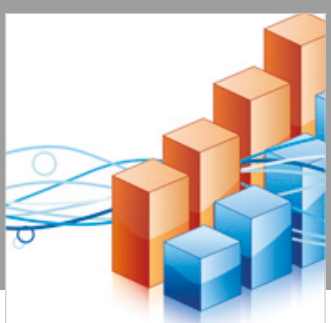

Advances in

Operations Research

\section{-n-m}
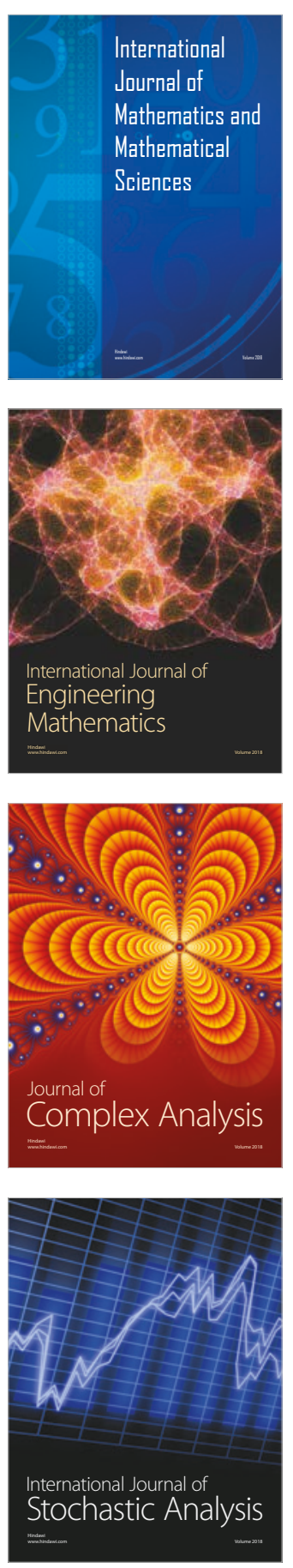
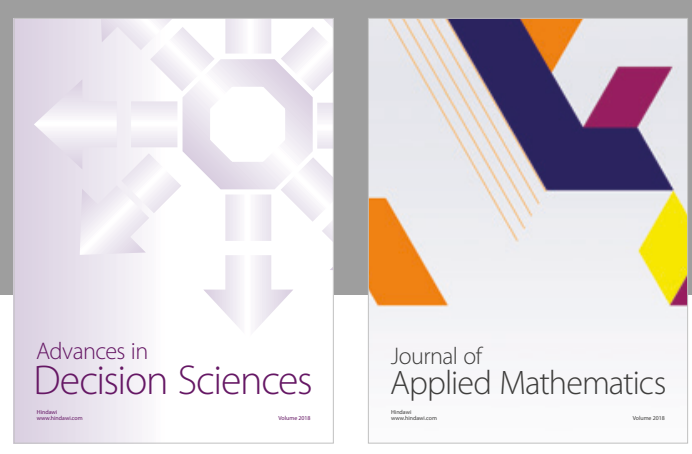

Journal of

Applied Mathematics
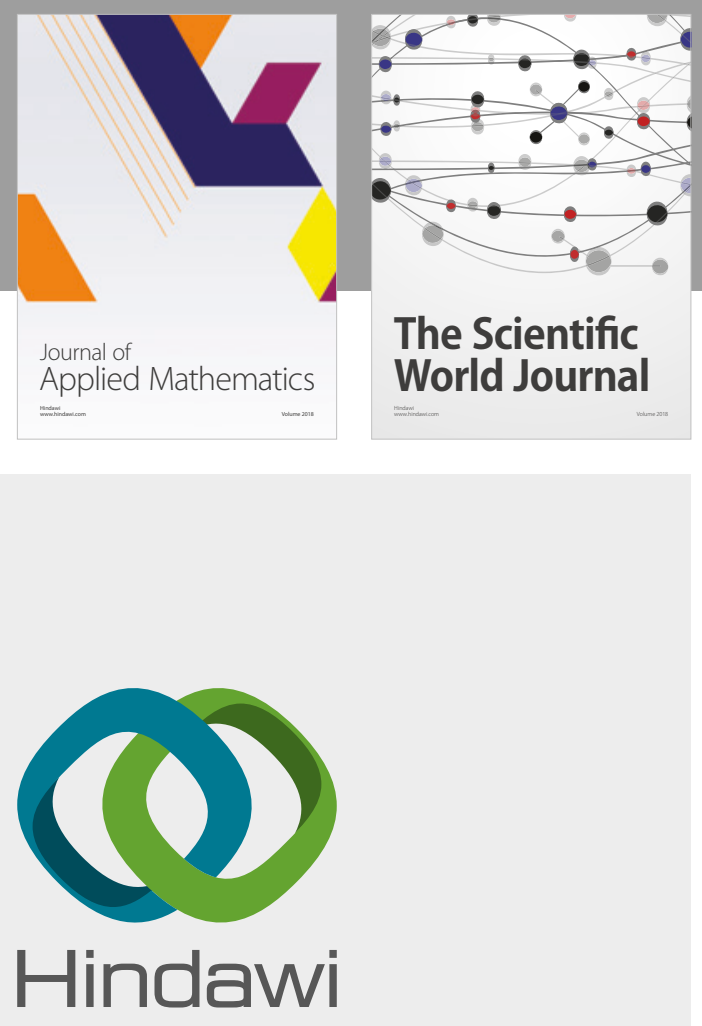

Submit your manuscripts at

www.hindawi.com

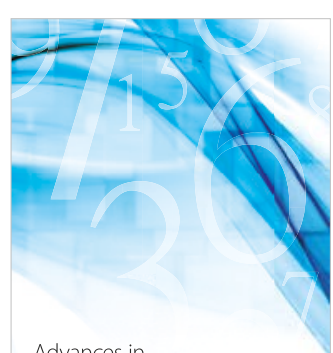

Advances in
Numerical Analysis
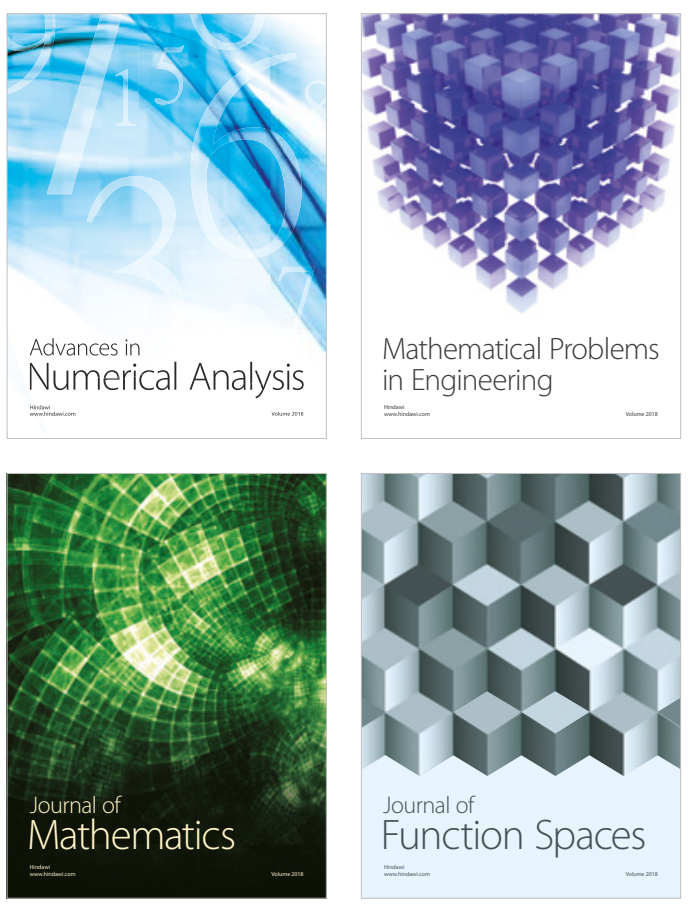

Mathematical Problems in Engineering

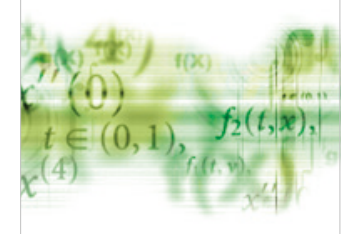

International Journal of

Differential Equations

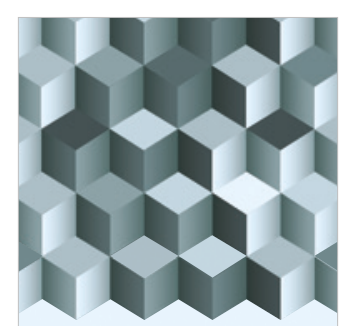

Journal of

Function Spaces
The Scientific

World Journal

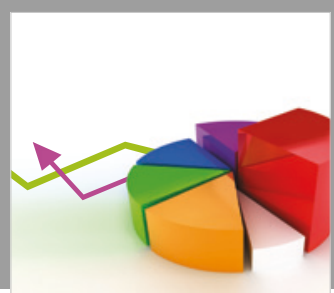

Journal of

Probability and Statistics
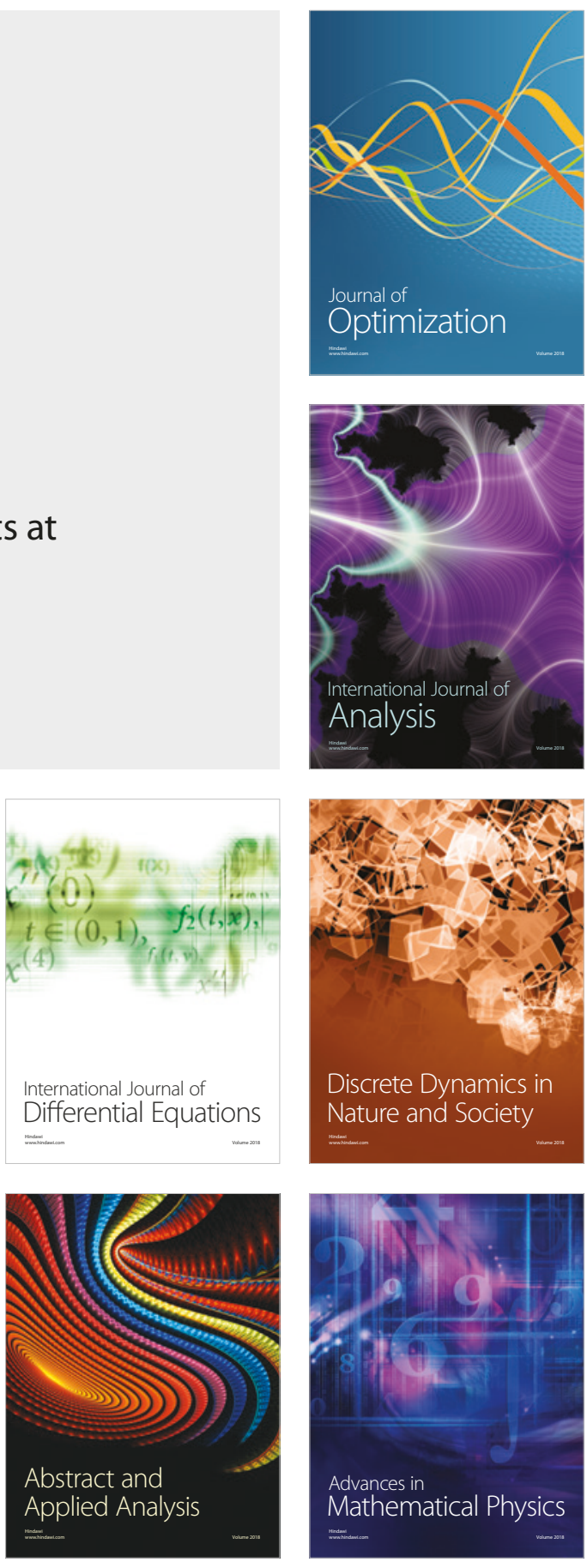